\title{
Iron and zinc effects on silicic acid and nitrate uptake kinetics in three high-nutrient, low-chlorophyll (HNLC) regions
}

\author{
Valerie M. Franck ${ }^{1,4, *}$, Kenneth W. Bruland ${ }^{2}$, David A. Hutchins ${ }^{3}$, Mark A. Brzezinski ${ }^{1}$ \\ ${ }^{1}$ Marine Science Institute and the Department of Ecology, Evolution and Marine Biology, University of California Santa \\ Barbara, Santa Barbara, California 93106, USA \\ ${ }^{2}$ Institute of Marine Sciences, University of California Santa Cruz, Santa Cruz, California 95064, USA \\ ${ }^{3}$ College of Marine Studies, University of Delaware, Lewes, Delaware 19958, USA
}

${ }^{4}$ Present address: School of Ocean and Earth Science and Technology, University of Hawaii, 1000 Pope Rd., Honolulu, Hawaii 96822, USA

\begin{abstract}
Effects of Fe and $\mathrm{Zn}$ availabilities on silicic acid $\left(\mathrm{Si}(\mathrm{OH})_{4}\right)$ and nitrate $\left(\mathrm{NO}_{3}{ }^{-}\right)$uptake kinetics in natural phytoplankton assemblages were investigated in 3 high-nutrient, low-chlorophyll (HNLC) regions: off central California, the Southern Ocean and the eastern tropical Pacific. Fe addition significantly increased the maximum potential uptake rate $\left(V_{\max }\right)$ of $\mathrm{Si}(\mathrm{OH})_{4}\left(\mathrm{Si} V_{\max }\right)$ by 2 to 3 times relative to controls in 8 of 10 experiments. Fe addition significantly increased the maximum potential uptake rate of nitrate $\left(\mathrm{NO}_{3}{ }^{-} V_{\max }\right)$ by 2 to 3 times in all 6 experiments measuring the effect of $\mathrm{Fe}$ on $\mathrm{NO}_{3}{ }^{-} V_{\max }$. Four experiments quantified the effect of $\mathrm{Zn}$ addition on $\mathrm{Si} V_{\max }$ and $\mathrm{NO}_{3}{ }^{-} V_{\max }$. $\mathrm{Zn}$ had a significant effect on $\mathrm{Si} V_{\max }$ in only 1 experiment, increasing values 2 -fold relative to controls. $\mathrm{Zn}$ addition had significant effects on $\mathrm{NO}_{3}{ }^{-} V_{\max }$ in 3 experiments, increasing $\mathrm{NO}_{3}{ }^{-} V_{\max }$ almost 2-fold in 1 instance and decreasing $\mathrm{NO}_{3}{ }^{-} V_{\max }$ by 23 to $46 \%$ in 2 instances. Combined Fe and $\mathrm{Zn}$ additions had effects on $\mathrm{Si}$ and $\mathrm{NO}_{3}{ }^{-} V_{\max }$ that were similar to those of Fe addition alone. In 4 experiments measuring Fe and $\mathrm{Zn}$ effects on the half-saturation constant $\left(K_{\mathrm{s}}\right)$ for $\mathrm{Si}(\mathrm{OH})_{4}$ uptake $\left(\mathrm{Si} K_{\mathrm{s}}\right)$, Fe addition increased Si $K_{\mathrm{s}}$ over 3 -fold relative to controls in one experiment and $\mathrm{Zn}$ addition decreased it by $61 \%$ in another. The effect of $\mathrm{Fe}$ and $\mathrm{Zn}$ addition on the half-saturation constant for $\mathrm{NO}_{3}{ }^{-}$uptake $\left(\mathrm{NO}_{3}{ }^{-} K_{\mathrm{s}}\right)$ could only be measured at 1 location. Here, Fe addition had no effect, and $\mathrm{Zn}$ addition alone and in combination with Fe decreased $\mathrm{NO}_{3}{ }^{-} K_{\mathrm{s}}$ by $68 \%$. $\mathrm{Si}(\mathrm{OH})_{4}: \mathrm{NO}_{3}{ }^{-}$drawdown ratios calculated from changes in nutrient concentrations during the experiments were very similar to Si $V_{\max }: \mathrm{NO}_{3}{ }^{-} V_{\max }$ ratios measured at the end of the experiments using tracers, and the effects of Fe and Zn addition on drawdown ratios paralleled the effects of $\mathrm{Fe}$ and $\mathrm{Zn}$ on $V_{\max }$ ratios. In general, changes in $\mathrm{Si}(\mathrm{OH})_{4}: \mathrm{NO}_{3}{ }^{-}$drawdown and $V_{\max }$ ratios were driven by changes in $\mathrm{NO}_{3}{ }^{-}$drawdown and $\mathrm{NO}_{3}{ }^{-} V_{\max }$. Our data show that $\mathrm{Fe}$ and $\mathrm{Zn}$ availabilities have a direct effect on $\mathrm{Si}(\mathrm{OH})_{4}$ and $\mathrm{NO}_{3}{ }^{-}$uptake kinetics in natural phytoplankton assemblages in HNLC regions, and that changes in kinetic parameters may be driving changes in nutrient drawdown ratios, providing further proof that Fe limitation may accelerate the 'silica pump' and lead to seasonal $\mathrm{Si}(\mathrm{OH})_{4}$ limitation. These results have significant implications for Si and N biogeochemistry and new production in low-Fe regions. Changes in nutrient uptake kinetics can also have important implications for phytoplankton species succession and ecological dynamics.
\end{abstract}

KEY WORDS: Nutrient uptake kinetics · Iron limitation · Zinc limitation · California · Eastern tropical Pacific $\cdot$ Southern Ocean

\section{INTRODUCTION}

Low Fe availability has been shown to limit phytoplankton growth and modify nutrient uptake ratios in high-nutrient, low-chlorophyll (HNLC) waters. New production, which governs carbon flux over seasonal time scales, is usually regulated by $\mathrm{NO}_{3}{ }^{-}$availability, although studies have shown that in HNLC regions, 
new production may be regulated by $\mathrm{Si}(\mathrm{OH})_{4}$ availability (Dugdale et al. 1995, Dugdale \& Wilkerson 1998). Fe limitation can reduce both $\mathrm{NO}_{3}{ }^{-}$and $\mathrm{Si}(\mathrm{OH})_{4}$ uptake (e.g. Price et al. 1991, Coale et al. 1996, Boyd et al. 1999, Franck et al. 2000), suggesting that Fe availability may also be regulating new production and $\mathrm{C}$ flux in HNLC regions.

While Fe limitation has received a lot of attention, previous laboratory studies have demonstrated that Zn limitation can also limit phytoplankton growth in culture (e.g. Anderson et al. 1978, Brand et al. 1983, Sunda \& Huntsman 1992). The link between Zn availability and $\mathrm{Si}(\mathrm{OH})_{4}$ and $\mathrm{NO}_{3}{ }^{-}$uptake, and thus new production, is less well known than that for $\mathrm{Fe}$, but there is laboratory evidence that $\mathrm{Zn}$ limitation can decrease $\mathrm{Si}(\mathrm{OH})_{4}$ uptake efficiency in diatoms (Rueter \& Morel 1981, De La Rocha et al. 2000), and reduce N uptake and protein synthesis in the autotrophic flagellate Euglena gracilis (Wacker 1962). These studies suggest that $\mathrm{Zn}$ as well as Fe availability might be regulating phytoplankton growth, nutrient drawdown and possibly new production in HNLC waters. Zn limitation has not yet been demonstrated in the field, but this may be because $\mathrm{Zn}$ limitation is more prevalent in coastal HNLC regions, which are not as wellstudied as open-ocean HNLC regions.

Liebig's law of the minimum sates that co-limitation, where phytoplankton growth and/or nutrient uptake is simultaneously limited by more than one factor, does not occur in natural phytoplankton populations. The possibility for co-limitation by Fe and another micronutrient such as $\mathrm{Zn}$, however, has been discussed in theory (Bruland et al. 1991). Fe and macronutrient colimitation may also occur. If $\mathrm{Fe}$ not only regulates phytoplankton growth rates but also has a direct effect on macronutrient uptake kinetics - for example, if $\mathrm{Fe}$ availability regulates the maximum capacity $\left(V_{\max }\right)$ or uptake efficiency $\left(K_{\mathrm{s}}\right)$ of a nutrient essential for growth-phytoplankton growth rates may be colimited by both Fe and nutrient availability. Recent evidence suggests that phytoplankton production in certain HNLC regions may in fact be simultaneously limited by both $\mathrm{Fe}$ and $\mathrm{Si}(\mathrm{OH})_{4}$ (Boyd et al. 1999, Franck et al. 2000, Hutchins et al. 2001).

Several studies in HNLC waters have documented that phytoplankton assemblages growing at ambient Fe concentrations have higher $\mathrm{Si}(\mathrm{OH})_{4}: \mathrm{NO}_{3}{ }^{-}$drawdown ratios than do those growing in Fe enrichments, despite reduced diatom abundance (Hutchins \& Bruland 1998, Takeda 1998). Higher $\mathrm{Si}(\mathrm{OH})_{4}: \mathrm{NO}_{3}{ }^{-}$drawdown ratios have the potential to alter regional Si biogeochemistry. For example, the occurrence of high $\mathrm{NO}_{3}{ }^{-}$, low $\mathrm{Si}(\mathrm{OH})_{4}$ surface waters, and the potential for Si limitation has been observed in most HNLC regions, including the subantarctic Southern Ocean (Boyd et al.
1999, Hutchins et al. 2001), the subarctic NE Pacific (Wong \& Matear 1999), the eastern tropical Pacific (Dugdale et al. 1995) and upwelling centers off central California (Bruland et al. 2001). One explanation for the occurrence of high- $\mathrm{NO}_{3}{ }^{-}$, low- $\mathrm{Si}(\mathrm{OH})_{4}$ regions is a process described in Dugdale et al. (1995) termed the 'silicate pump'. The silicate pump works to export $\mathrm{Si}(\mathrm{OH})_{4}$ to deeper waters more efficiently than $\mathrm{NO}_{3}{ }^{-}$, due to the faster regeneration rates of $\mathrm{N}$ in surface waters relative to $\mathrm{Si}$, and to the enhanced export of $\mathrm{Si}$ that can occur when frustules are repackaged into fecal pellets. Higher $\mathrm{Si}(\mathrm{OH})_{4}: \mathrm{NO}_{3}{ }^{-}$drawdown ratios, however, could also explain the presence of these low-Fe, low-Si(OH) ${ }_{4}$, high- $\mathrm{NO}_{3}{ }^{-} \mathrm{HNLC}$ regions (De La Rocha et al. 2000, Firme et al. 2003).

Despite the biogeochemical importance of high $\mathrm{Si}(\mathrm{OH})_{4}: \mathrm{NO}_{3}{ }^{-}$drawdown ratios, the processes driving them remain unclear. Several theories have been used to explain usually high $\mathrm{Si}(\mathrm{OH})_{4}: \mathrm{NO}_{3}{ }^{-}$drawdown and uptake ratios, including the growth of more heavily silicified diatoms or a reduction in $\mathrm{N}$ and $\mathrm{C}$ uptake relative to $\mathrm{Si}$ uptake. In this paper, we test the hypothesis that a differential effect of Fe on the maximum potential uptake rates of $\mathrm{Si}(\mathrm{OH})_{4}$ and $\mathrm{NO}_{3}{ }^{-}-$ namely, that low-Fe conditions lead to stronger reductions in $\mathrm{NO}_{3}^{-}$uptake capacity relative to $\mathrm{Si}$ uptake capacity-could be causing higher $\mathrm{Si}(\mathrm{OH})_{4}: \mathrm{NO}_{3}{ }^{-}$ drawdown ratios. Field studies were conducted in 3 HNLC regions: upwelling areas off California, the eastern tropical Pacific and the Pacific sector of the Southern Ocean. These regions, although potentially highly productive, in general have high macronutrient concentrations, low dissolved Fe concentrations and relatively low biomass (e.g. Southern Ocean: Martin et al. 1990; eastern tropical Pacific: Coale et al. 1996; California: Bruland et al. 2001). Although the upwelling center off central California is not regarded as a classic HNLC region, areas within this upwelling center consistently have the high concentrations of $\mathrm{Si}(\mathrm{OH})_{4}, \mathrm{NO}_{3}{ }^{-}$and $\mathrm{PO}_{4}{ }^{3-}$ and relatively low concentrations of phytoplankton biomass that are typical of other traditionally defined HNLC areas (Bruland et al. 2001). In addition, several studies have demonstrated that $\mathrm{Fe}$ availability can regulate nutrient drawdown and chlorophyll concentration in these upwelling regions (Hutchins \& Bruland 1998, Hutchins et al. 1998, Firme et al. 2003).

In this study we document the first field evidence that both $\mathrm{Fe}$ and $\mathrm{Zn}$ availabilities can significantly affect $\mathrm{Si}(\mathrm{OH})_{4}$ and $\mathrm{NO}_{3}^{-}$uptake kinetics in natural phytoplankton assemblages. The persistently high nutrient concentrations observed in HNLC regions have been attributed to low phytoplankton growth rates, low phytoplankton biomass and the dominance of picophytoplankton as a result of micronutrient limitation. 
Our data suggest that $\mathrm{Fe}$ and $\mathrm{Zn}$ availabilities may have a more direct role than previously thought in causing high nutrient concentrations in HNLC regions through the regulation of nutrient uptake kinetics. By regulating $\mathrm{NO}_{3}{ }^{-}$uptake kinetics in particular, Fe and $\mathrm{Zn}$ availabilities may have a direct influence on the rate of new production and potential $\mathrm{C}$ export as well. We suggest that $\mathrm{Fe}$ effects on $\mathrm{Si}(\mathrm{OH})_{4}$ and $\mathrm{NO}_{3}{ }^{-}$kinetics may also explain the unusually high $\mathrm{Si}(\mathrm{OH})_{4}: \mathrm{NO}_{3}{ }^{-}$drawdown and uptake ratios observed in HNLC regions.

\section{MATERIALS AND METHODS}

Ten shipboard bottle enrichment experiments were conducted from 1997 to 2000 in waters with variable concentrations of $\mathrm{Si}(\mathrm{OH})_{4}, \mathrm{NO}_{3}{ }^{-}$and $\mathrm{PO}_{4}{ }^{3-}$, and relatively low concentrations of dissolved $\mathrm{Fe}$ and $\mathrm{Zn}$ (Table 1). Experimental locations included 3 areas in an upwelling region off the central California coast (Fig. 1a), 4 areas in the Pacific sector of the Southern Ocean visited during the US JGOFS AESOPS study (Fig. 1b), and 3 upwelling regions in the eastern tropical Pacific (Fig. 1c). In order to measure the effect of Fe and $\mathrm{Zn}$ availability on nutrient uptake kinetics, Fe and Zn enrichments were started by incubating whole seawater collected using trace-metal clean techniques in 10 to 201 carboys on deck, either unaltered (as controls) or with various additions of dissolved Fe and/or Zn. After several days, nutrient uptake kinetics were measured in each enrichment. In general, kinetics parameters were measured in controls and at one concentration of added Fe and Zn. In the Southern Ocean experiments, however, Si $V_{\max }$ was measured at 4 concentrations of added Fe. Concentrations of added $\mathrm{Fe}$ and $\mathrm{Zn}$, as well as the kinetic parameters measured, varied among experiments (Table 2). Fe and Zn additions were higher at the sites located off the California coast, as coastal phytoplankton typically have higher metal requirements than open-ocean phytoplankton (e.g. Brand et al. 1983, Sunda et al. 1991, Sunda \& Huntsman 1992).

Shipboard enrichment experiments. California upwelling region: A total of 3 experiments were conducted in newly upwelled coastal waters at 3 different locations off central California: Big Sur (1997), Pt Arena (1999) and Pt Conception (1999) (Table 1, Fig. 1a). Initial concentrations of total dissolved Fe and $\mathrm{Zn}(<0.2 \mu \mathrm{m}$ fraction) in the seawater used in these experiments varied from 0.03 to $0.10 \mathrm{nM}$ Fe and 0.07 to $0.2 \mathrm{nM} \mathrm{Zn}$ (Table 1). Concentrations of dissolved Fe and $\mathrm{Zn}$ were quantified at sea under trace-metal clean conditions using cathodic stripping voltammetry (Rue \& Bruland 1995, 1997) or in the laboratory using solvent extraction and graphite furnace atomic absorption spectrometry (Bruland et al. 1979).

Seawater for the enrichment experiments was collected from 5 to $15 \mathrm{~m}$ depth using a clean pumping system (Hutchins et al. 1998). Unfiltered water was first mixed in a 501 acid-cleaned carboy, and a subsample of surface water was retained for measurements of in situ nutrient and biomass concentrations and $\mathrm{Si}(\mathrm{OH})_{4}$ and $\mathrm{NO}_{3}^{-}$uptake rates. Enrichments were conducted in 101 acid-cleaned polycarbonate carboys. The Big Sur experiment involved 3 enrichment carboys: 1 control (no additions), 1 Fe addition (+10 nM Fe) and $1 \mathrm{Zn}$

Table 1. Sampling dates, locations and ambient micro- and macronutrient ( $\mathrm{Fe}, \mathrm{Zn}, \mathrm{NO}_{3}^{-}, \mathrm{Si}, \mathrm{PO}_{4}$ ) and biomass (chl a, particulate organic carbon, $\mathrm{POC}$, and nitrogen, $\mathrm{PON}$, and biogenic silica, $\mathrm{bSiO}_{2}$ ) concentrations for 10 trace-metal enrichment experiments conducted in waters off the coast of central California, in the Pacific sector of the Southern Ocean and in the eastern tropical Pacific. Southern Ocean ambient $\mathrm{Fe}, \mathrm{Zn}, \mathrm{NO}_{3}^{-}, \mathrm{PO}_{4}, \mathrm{chl} a, \mathrm{POC}$ and PON concentrations are from Coale et al. (2003). na: data not available

\begin{tabular}{|c|c|c|c|c|c|c|c|c|c|c|c|}
\hline \multirow{2}{*}{$\begin{array}{l}\text { Region } \\
\quad \text { Experiment }\end{array}$} & \multirow[b]{2}{*}{ Date } & \multirow[b]{2}{*}{ Location } & \multicolumn{5}{|c|}{ Initial nutrients } & \multicolumn{4}{|c|}{ Initial biomass } \\
\hline & & & $\begin{array}{l}\mathrm{Fe} \\
(\mathrm{nM})\end{array}$ & $\begin{array}{c}\mathrm{Zn} \\
(\mathrm{nM})\end{array}$ & $\begin{array}{l}\mathrm{NO}_{3}^{-} \\
(\mu \mathrm{M})\end{array}$ & $\begin{array}{c}\mathrm{Si} \\
(\mu \mathrm{M})\end{array}$ & $\begin{array}{l}\mathrm{PO}_{4} \\
(\mu \mathrm{M})\end{array}$ & $\begin{array}{c}\mathrm{Chl} \mathrm{a} \\
\left(\mathrm{mg} \mathrm{m}^{-3}\right)\end{array}$ & $\begin{array}{c}\text { POC } \\
\left(\mu \mathrm{mol} \mathrm{l}^{-1}\right)\end{array}$ & $\begin{array}{c}\text { PON } \\
\left(\mu \mathrm{mol} \mathrm{l}^{-1}\right)\end{array}$ & $\begin{array}{c}\mathrm{bSiO}_{2} \\
\left(\mu \mathrm{mol} \mathrm{l}^{-1}\right)\end{array}$ \\
\hline \multicolumn{12}{|l|}{ California } \\
\hline Big Sur & 21 Jun 97 & $37.0^{\circ} \mathrm{N}, 122.0^{\circ} \mathrm{W}$ & 0.10 & 0.07 & 12.3 & 15.1 & na & 0.54 & 7.8 & 0.8 & 0.2 \\
\hline Pt Arena & 25 Jun 99 & $38.3^{\circ} \mathrm{N}, 124.3^{\circ} \mathrm{W}$ & 0.03 & 0.2 & 8.3 & 3.4 & 0.4 & 1.62 & 19.4 & 3.1 & 3.8 \\
\hline Pt Conception & 28 Jun 99 & $35.0^{\circ} \mathrm{N}, 121.5^{\circ} \mathrm{W}$ & 0.06 & 0.1 & 8.7 & 8.8 & 0.7 & 1.23 & 20.1 & 3.2 & 2.8 \\
\hline \multicolumn{12}{|c|}{ Southern Ocean } \\
\hline Expt 1 & 28 Oct 97 & $62.3^{\circ} \mathrm{S}, 170.0^{\circ} \mathrm{W}$ & 0.10 & 2.84 & 31.1 & 47.2 & 2.1 & 0.33 & 4.0 & 0.7 & 0.4 \\
\hline Expt 2 & 05 Nov 97 & $59.2^{\circ} \mathrm{S}, 170.0^{\circ} \mathrm{W}$ & 0.06 & 0.92 & 26.8 & 15.4 & 1.8 & 0.29 & 2.8 & 0.6 & 0.2 \\
\hline Expt 3 & 17 Jan 98 & $67.8^{\circ} \mathrm{S}, 170.1^{\circ} \mathrm{W}$ & 0.02 & 1.01 & 25.1 & 60.8 & 1.6 & 0.96 & 17.2 & 2.5 & 3.3 \\
\hline Expt 4 & 20 Jan 98 & $62.0^{\circ} \mathrm{S}, 170.1^{\circ} \mathrm{W}$ & 0.11 & 0.18 & 22.5 & 5.1 & 1.4 & 0.36 & 10.3 & 1.6 & 5.1 \\
\hline \multicolumn{12}{|c|}{ Eastern tropical Pacific } \\
\hline Costa Rica & 30 Aug 00 & $08.7^{\circ} \mathrm{N}, 090.6^{\circ} \mathrm{W}$ & 0.13 & na & 4.4 & 7.2 & 0.9 & 0.49 & 25.5 & 3.7 & 0.1 \\
\hline Humboldt & 08 Sep 00 & $03.8^{\circ} \mathrm{S}, 085.3^{\circ} \mathrm{W}$ & 0.10 & 0.06 & 11.0 & 6.3 & 0.6 & 0.54 & 12.9 & 1.3 & 0.7 \\
\hline Peru & 19 Sep 00 & $14.3^{\circ} \mathrm{S}, 078.4^{\circ} \mathrm{W}$ & 0.30 & 0.10 & 3.2 & 4.3 & 0.7 & 0.90 & 16.4 & 1.6 & 0.4 \\
\hline
\end{tabular}


addition (+2 nM Zn). The Pt Arena and Pt Conception experiments each involved 5 enrichment carboys: 2 controls (no additions), 1 Fe addition (+10 nM), 1 Zn addition $(+2 \mathrm{nM})$ and 1 combined $\mathrm{Fe}$ and $\mathrm{Zn}$ addition (+10 nM Fe, +2 nM Zn). Metal additions were made from $26 \mu \mathrm{M}$ inorganic $\mathrm{Fe}^{3+}$ and $\mathrm{Zn}^{2+}$ stocks prepared in $0.01 \mathrm{~N}$ Ultrex $\mathrm{HCl}$. All enrichment carboys were handled under a Class 100 laminar flow hood using trace-metal clean techniques. After filling and handling, enrichment carboys were sealed with parafilm and incubated at surface temperatures and $40 \%$ ambient light in flow-though incubators lined with blue plexiglass (Hutchins et al. 1993). Enrichments were incubated for at least $3 \mathrm{~d}$ prior to measuring uptake kinetics, as trace-metal bottle enrichments typically show a 1 to $3 \mathrm{~d}$ lag period before a response to metal addition is observed. Details of all 3 experiments are listed in Table 2.
Eastern tropical Pacific: Three enrichment experiments were conducted in September 2000 in 3 different regions of the eastern tropical Pacific: the Costa Rica Upwelling Dome, the Humboldt Current region and the Peruvian upwelling region (Table 1, Fig. 1b). Initial dissolved $\mathrm{Fe}$ concentrations were 0.10 to $0.30 \mathrm{nM}$ Fe and 0.06 to $0.10 \mathrm{nM} \mathrm{Zn}$ (Table 1). No data yet exists for initial dissolved $\mathrm{Zn}$ concentrations in the Costa Rica Upwelling Dome experiment.

Experimental methods were almost identical to those in waters off California, except that here all enrichments were replicated in triplicate and concentrations of added Fe and Zn were lower. Briefly, six 101 acidcleaned polycarbonate carboys were filled with whole seawater under trace-metal clean conditions. Three enrichment carboys were treated as controls (no additions) and 3 were treated as Fe enrichments (+2 nM $\mathrm{Fe})$. At the Costa Rica Upwelling Dome location, an
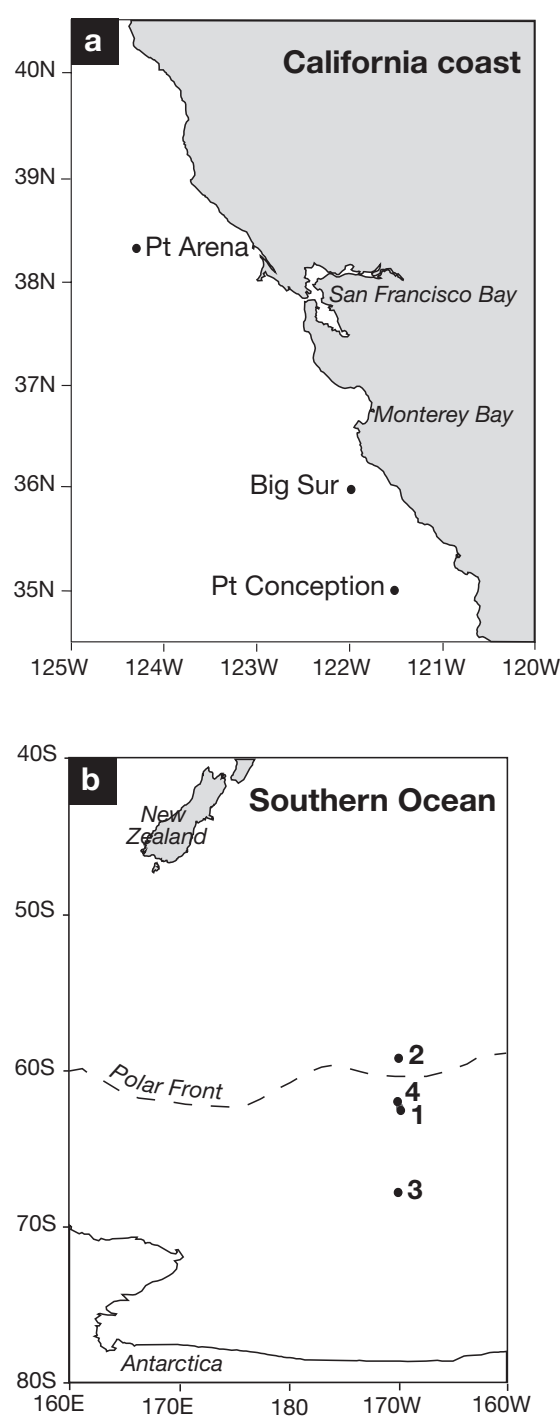

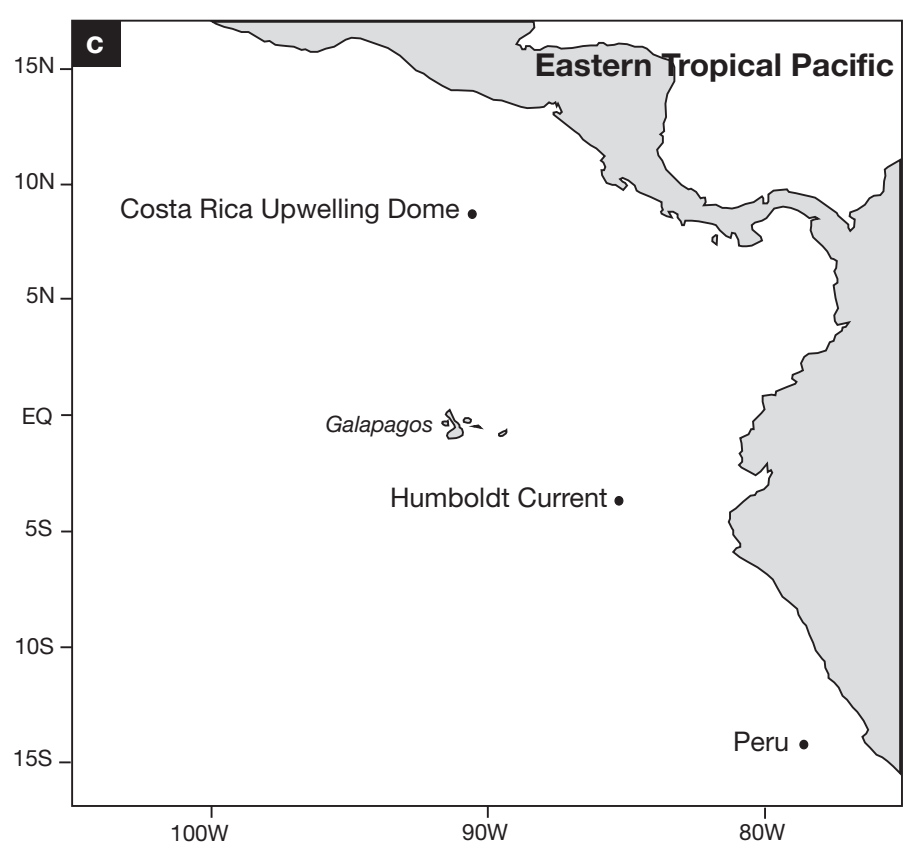

Fig. 1. Locations of 10 enrichment experiments conducted in (a) waters off central California, (b) the Pacific sector of the Southern Ocean and (c) the eastern tropical Pacific 
additional 6 enrichment carboys were filled as described above. Three of these were treated as $\mathrm{Zn}$ additions (+1 nM Zn) and the remaining 3 were treated as combined Fe and $\mathrm{Zn}$ additions (+2 $\mathrm{nM} \mathrm{Fe},+1 \mathrm{nM} \mathrm{Zn)}$. At all locations, carboys were sealed with parafilm and incubated for 3 to $6 \mathrm{~d}$ in flow-through incubators on deck with neutral density screening at $~ 50 \%$ ambient light. For additional details, see Tables $1 \& 2$.

Southern Ocean: Four enrichment experiments were conducted in austral spring and summer 1997-98 in the Pacific sector of the Southern Ocean near the Polar Frontal Zone as part of the US Southern Ocean AESOPS study (Smith et al. 2000): 1 north of the Polar Front (Expt 2), 2 within the Frontal Zone (Expts 1 and 4 ) and 1 south of the Front (Expt 3) (Table 1, Fig. 1c). Initial dissolved Fe concentrations ranged from 0.02 to $0.06 \mathrm{nM}$ north and south of the front and from 0.10 to $0.11 \mathrm{nM}$ at the front. Initial dissolved $\mathrm{Zn}$ concentrations ranged from 0.18 to $2.84 \mathrm{nM}$. Enrichment experiments were conducted using methods similar to those described in Coale 1991. Whole seawater was collected using trace-metal clean GoFlo bottles suspended on Kevlar line and distributed into $8 \times 201$ acid-washed polycarbonate carboys under Class 100 conditions. Two enrichment carboys were treated as controls (no additions), 4 carboys were treated as Fe additions (+0.2 nM Fe, +0.5 nM Fe, +1.0 nM Fe, +2.5 nM Fe), 1 carboy was treated as a $\mathrm{Zn}$ addition (+5 nM Zn) and 1 carboy was treated as a combined $F$ e and $Z n$ addition (+2.5 nM Fe, +5 nM Zn). Enrichment carboy lids were sealed with plastic bags and incubated at full ambient light in on-deck flow-through incubators for 8 to $16 \mathrm{~d}$. Subsamples for $\mathrm{Si}(\mathrm{OH})_{4}, \mathrm{NO}_{3}{ }^{-}$and biogenic silica $\left(\mathrm{SiO}_{2}\right)$ concentrations, $\mathrm{Si}(\mathrm{OH})_{4}$ and $\mathrm{NO}_{3}{ }^{-}$uptake rates and Si $V_{\max }$ were withdrawn at 1 to $5 \mathrm{~d}$ intervals using clean techniques after an initial lag period of 5 to $8 \mathrm{~d}$. See Table 2 and Franck et al. (2000) for details. Light levels inside the carboys during incubation were higher than those in situ (Franck et al. 2000), and white-light photoinhibition could have occurred in the enrichments on clear days. Overcast conditions predominated during each experiment, however.

$\mathrm{Si}(\mathrm{OH})_{4}$ and $\mathrm{NO}_{3}{ }^{-}$uptake. Nutrient uptake rates and uptake kinetics were measured using the radiotracer ${ }^{32} \mathrm{Si}$ and the stable isotope ${ }^{15} \mathrm{~N}$. $\mathrm{Si}(\mathrm{OH})_{4}: \mathrm{NO}_{3}{ }^{-}$drawdown ratios were calculated from changes in $\mathrm{Si}(\mathrm{OH})_{4}$ and $\mathrm{NO}_{3}{ }^{-}$concentrations in the enrichments during the course of the experiments. Si uptake kinetics were measured by distributing water from enrichment carboys into 125 to $250 \mathrm{ml}$ acid-cleaned polycarbonate bottles. Bottles received 1 addition of cold $\mathrm{Si}(\mathrm{OH})_{4}$, ranging from 0 to $50 \mu \mathrm{M}$, and were then spiked with $1000 \mathrm{~Bq}$ of trace-metal clean ${ }^{32} \mathrm{Si}$ (adding $<18 \mathrm{nM}$ $\left.\mathrm{Si}[\mathrm{OH}]_{4}\right)$. Cold $\mathrm{Si}(\mathrm{OH})_{4}$ additions were made from a trace-metal clean stock solution of $\mathrm{Na}_{2} \mathrm{SiO}_{3} . \mathrm{NO}_{3}$ uptake kinetics were measured by distributing water from the same enrichment carboys into 250 to $500 \mathrm{ml}$ acid-cleaned polycarbonate bottles. Each bottle received 1 addition of ${ }^{15} \mathrm{NO}_{3}{ }^{-}$ranging from 0.25 to $30 \mu \mathrm{M}$. Additions were made from a trace-metal clean stock solution of $\mathrm{Na}^{15} \mathrm{NO}_{3}$.

Full $\mathrm{Si}(\mathrm{OH})_{4}$ and $\mathrm{NO}_{3}{ }^{-}$kinetic curves, including $V_{\max }$ and $K_{\mathrm{s}}$ measurements, were conducted in 4 enrichment experiments: Big Sur, Pt Arena and Pt Conception off California and the Costa Rica Upwelling Dome in the eastern tropical Pacific (Table 2). Curves included 8 concentrations of added $\mathrm{Si}(\mathrm{OH})_{4}(0$ to $20 \mu \mathrm{M})$ and 7 concentrations of added $\mathrm{NO}_{3}{ }^{-}(0.25$ to $10 \mu \mathrm{M})$ and bottles were incubated for $\sim 7 \mathrm{~h}$, spanning localtime noon.

In the Southern Ocean experiments and in the Humboldt and Peru experiments, $K_{\mathrm{s}}$ values were not measured (Table 2). For the Southern Ocean experiments, $\mathrm{Si}(\mathrm{OH})_{4}$ uptake rates were measured in seawater samples incubated for $24 \mathrm{~h}$ at ambient and saturating $\mathrm{Si}(\mathrm{OH})_{4}$ concentrations $(+0 \mu \mathrm{M}$ and +40 to $50 \mu \mathrm{M}$,

Table 2. Enrichment volumes, durations and Fe and Zn additions in 10 enrichment experiments conducted off California, in the Southern Ocean and in the eastern tropical Pacific. -: no enrichment done

\begin{tabular}{|c|c|c|c|c|c|c|}
\hline \multirow[t]{2}{*}{ Region } & \multirow{2}{*}{ Experiment } & \multirow{2}{*}{$\begin{array}{l}\text { Volume } \\
\text { (l) }\end{array}$} & \multirow{2}{*}{$\begin{array}{l}\text { Duration } \\
\text { (d) }\end{array}$} & \multicolumn{3}{|c|}{ Enrichment additions } \\
\hline & & & & $\begin{array}{l}\mathrm{Fe} \\
(\mathrm{nM})\end{array}$ & $\begin{array}{c}\mathrm{Zn} \\
(\mathrm{nM})\end{array}$ & $\begin{array}{c}\mathrm{Fe}+\mathrm{Zn} \\
(\mathrm{nM} \mathrm{Fe} / \mathrm{nM} \mathrm{Zn})\end{array}$ \\
\hline \multirow[t]{3}{*}{ California } & Big Sur & 10 & 3 & 10 & 2 & - \\
\hline & Pt Arena & 10 & 3 & 10 & 2 & $10 / 2$ \\
\hline & Pt Conception & 10 & 3.5 & 10 & 2 & $10 / 2$ \\
\hline \multirow[t]{4}{*}{ Southern Ocean } & Expt 1 & 20 & $5-16$ & $0.2,0.5,1.0,2.5$ & 5 & $2.5 / 5$ \\
\hline & Expt 2 & 20 & $5-8$ & $0.2,0.5,1.0,2.5$ & 5 & $2.5 / 5$ \\
\hline & Expt 3 & 20 & $6-10$ & $0.2,0.5,1.0,2.5$ & 5 & $2.5 / 5$ \\
\hline & Expt 4 & 20 & $8-16$ & $0.2,0.5,1.0,2.5$ & 5 & $2.5 / 5$ \\
\hline \multirow[t]{3}{*}{ Eastern tropical Pacific } & Costa Rica & 10 & 6 & 2 & 1 & $2 / 1$ \\
\hline & Humboldt & 10 & 3 & 2 & - & - \\
\hline & Peru & 10 & 4 & 2 & - & - \\
\hline
\end{tabular}


respectively), yielding measurements of ambient $\mathrm{Si}(\mathrm{OH})_{4}$ uptake rates and $\mathrm{Si} V_{\text {max }} \cdot \mathrm{NO}_{3}{ }^{-}$uptake was measured at ambient concentrations only. Measurements were not replicated. Ambient $\mathrm{Si}(\mathrm{OH})_{4}$ and $\mathrm{NO}_{3}{ }^{-}$ uptake rates for the Southern Ocean experiments have been published elsewhere (Franck et al. 2000). In Humboldt and Peru experiments, $\mathrm{Si}(\mathrm{OH})_{4}$ and $\mathrm{NO}_{3}{ }^{-}$ uptake rates were measured in triplicate seawater samples incubated for 12 to $24 \mathrm{~h}$ at ambient and saturating $\mathrm{Si}(\mathrm{OH})_{4}$ and $\mathrm{NO}_{3}{ }^{-}$concentrations $(+0 \mu \mathrm{M}$ and +25 to $30 \mu \mathrm{M} \mathrm{Si}(\mathrm{OH})_{4 i}+0.25 \mu \mathrm{M}$ and +15 to $30 \mu \mathrm{M}$ $\mathrm{NO}_{3}{ }^{-}$), yielding measurements of ambient $\mathrm{Si}(\mathrm{OH})_{4}$ and $\mathrm{NO}_{3}{ }^{-}$uptake rates and Si $V_{\text {max }}$ and $\mathrm{NO}_{3}{ }^{-} V_{\text {max }}$.

After incubation, samples were vacuum-filtered (<150 mm Hg) onto $0.6 \mu \mathrm{m}$ polycarbonate filters and allowed to air dry $\left({ }^{32} \mathrm{Si}\right)$ or filtered onto pre-combusted Whatman GF/F glass fiber filters $(\sim 0.7 \mathrm{~mm})$ and stored frozen in pre-combusted aluminum foil packets $\left({ }^{15} \mathrm{~N}\right)$. Samples with ${ }^{32} \mathrm{Si}$ were stored until ${ }^{32} \mathrm{Si}$ and ${ }^{32} \mathrm{P}$ reached secular equilibrium (>3 mo) and ${ }^{32} \mathrm{Si}$ activity was assayed according to Brzezinski \& Phillips (1997). $\mathrm{Si}(\mathrm{OH})_{4}$ uptake rates were calculated as described therein. Samples with ${ }^{15} \mathrm{~N}$ were dried for $3 \mathrm{~d}$ at $65^{\circ} \mathrm{C}$ and atom $\%{ }^{15} \mathrm{~N}$ was analyzed on a Europa Scientific Tracer Mass or 20-20 mass spectrometer. $\mathrm{NO}_{3}{ }^{-}$uptake rates were calculated using equations in Dugdale \& Goering (1967). These values compared well with $\mathrm{NO}_{3}{ }^{-}$uptake rates calculated using equations adapted from Brzezinski \& Phillips (1997).

Kinetics parameters were calculated using the Michaelis-Menten equation:

$$
V=\frac{V_{\max } \times S}{K_{\mathrm{s}}+S}
$$

where $V$ is the uptake rate $\left(\mathrm{d}^{-1}\right), V_{\max }$ is the maximum potential uptake rate $\left(\mathrm{d}^{-1}\right), S$ is the substrate concentration $(\mu \mathrm{M})$ and $K_{\mathrm{s}}$ is the half-saturation constant $(\mu \mathrm{M})$, or the substrate concentration at which $V$ is onehalf $V_{\max } . V_{\max }$ and $K_{\mathrm{s}}$ parameters and their standard errors were estimated by fitting the data points in each kinetic curve to a rectangular hyperbolic non-linear regression using SigmaPlot software (SPSS). Kinetics parameters from metal enrichments were compared with kinetics parameters from corresponding control enrichments using paired Student's $t$-tests. In all cases but one, data for individual kinetic curves passed normality tests incorporated into the Sigma-Plot nonlinear regression analysis. When treatments were replicated, kinetic data from all curves were combined for 1 averaged curve fit. Unpublished data from kinetic experiments conducted in oligotrophic waters off Baja, Mexico show that replicate $\mathrm{Si}(\mathrm{OH})_{4}$ and $\mathrm{NO}_{3}{ }^{-}$kinetics using this method yield results with $<10 \%$ variability.

Phytoplankton community composition and cell counts. In order to determine whether changes in
$\mathrm{Si}(\mathrm{OH})_{4}$ and $\mathrm{NO}_{3}^{-}$uptake kinetics could be due to changes in phytoplankton species composition, samples for phytoplankton cell counts were taken in experiments off California (Pt Arena and Pt Conception) and in the eastern tropical Pacific (Costa Rica Upwelling Dome, Humboldt and Peru). Phytoplankton samples were preserved and analyzed using methods to ensure accurate diatom counts, as diatoms are the major contributors to $\mathrm{Si}(\mathrm{OH})_{4}$ uptake and tend to dominate $\mathrm{NO}_{3}{ }^{-}$ uptake in high-nitrate environments. Whole-water samples were preserved with acid formalin and stored in the dark at $10^{\circ} \mathrm{C}$ until analyzed (Throndsen 1978). In the laboratory, 10 to $50 \mathrm{ml}$ subsamples were settled in Hydrobios Utermöhl chambers and cells were identified and counted in randomized fields of view using an inverted light microscope (Leitz/Wetzlar Diavert) at $320 \times$ magnification, until a total of 400 cells or 20 fields were counted. When further magnification was necessary, valves were acid-cleaned and permanent mounts were made in mounting media with a high index of refraction (MeltMount 1.704, Cargille). Valves were then identified and enumerated at $1000 \times$. Identification was made using Cupp (1943) and Tomas (1997). Standard errors were calculated from replicate fields (5 to 20). Synechococcus spp. as well as bacteria are also known to utilize $\mathrm{NO}_{3}{ }^{-}$(Glover et al. 1988, Kirchman et al. 1992), although both groups exhibit a strong preference for $\mathrm{NH}_{4}{ }^{+}$and probably rely almost entirely on $\mathrm{NH}_{4}{ }^{+}$as a nitrogen source in low-Fe waters (Kudo \& Harrison 1997). For this reason, no effort was made to enumerate picophytoplankton and bacteria in the enrichments.

\section{RESULTS}

Values for $\mathrm{Si}(\mathrm{OH})_{4}$ and $\mathrm{NO}_{3}^{-} V_{\text {max }}$ varied widely among the 10 experiments in our study, but fall well within the range of previously reported values from other field and laboratory experiments. Values for $\mathrm{Si}$ $V_{\max }$ varied almost 30 -fold, ranging from 0.049 to $0.699 \mathrm{~d}^{-1}$ in the controls and 0.075 to $1.397 \mathrm{~d}^{-1}$ in treatments with added Fe and/or Zn (Table 3, Figs. 2 \& 3). The lowest $\mathrm{Si} V_{\max }$ values were observed in the Southern Ocean experiments (overall range 0.049 to $0.471 \mathrm{~d}^{-1}$ ) (Fig. 2). Other studies on $\mathrm{Si}(\mathrm{OH})_{4}$ uptake kinetics in the Southern Ocean report similarly low $V_{\max }$ values (e.g. Nelson et al. 2001). The highest $\mathrm{Si}$ $V_{\max }$ values $\left(0.699\right.$ to $1.397 \mathrm{~d}^{-1}$ ) were observed in the Costa Rica Upwelling Dome experiment conducted in the eastern tropical Pacific. Values for $\mathrm{NO}_{3}^{-} V_{\text {max }}$ in this study varied almost 40 -fold, ranging from 0.109 to $0.299 \mathrm{~d}^{-1}$ in the controls to 0.025 to $0.759 \mathrm{~d}^{-1}$ in treatments with added Fe and/or Zn (Table 3, Fig. 4). Some of the lowest $\mathrm{NO}_{3}{ }^{-} V_{\text {max }}$ values were observed in the $\mathrm{Zn}$ 
enrichments. The range in $\mathrm{NO}_{3}{ }^{-} V_{\max }$ values was similar among the 6 experiments conducted in the California and eastern tropical Pacific upwelling zones. There are no $\mathrm{NO}_{3}^{-} V_{\max }$ values from the Southern Ocean experiments for comparison.

$K_{\mathrm{s}}$ values for $\mathrm{Si}(\mathrm{OH})_{4}$ uptake in this study ranged from 0.75 to $7.11 \mu \mathrm{M}$ (Table 4, Fig. 3), and agree well with the mostly commonly reported $\mathrm{Si} K_{\mathrm{s}}$ values in the literature ( 0.5 to $5 \mu \mathrm{M}$; Martin-Jézéquel et al. 2001, Nelson et al. 2001). Estimates of $\mathrm{NO}_{3}{ }^{-} K_{\mathrm{S}}$ values ranged from 0.46 to $1.93 \mu \mathrm{M}$ (Table 4, Fig. 4), again agreeing well with the most commonly reported values for $\mathrm{NO}_{3}{ }^{-}$ $K_{\mathrm{s}}(\sim 0.02$ to $4 \mu \mathrm{M}$; e.g. Eppley et al. 1969, Kanda et al. 1985, Harrison et al. 1996).

Initial concentrations of dissolved $\mathrm{Fe}$ and $\mathrm{Zn}$ varied 10- and 40-fold, respectively, in the 10 enrichment experiments in this study, ranging from 0.03 to $0.30 \mathrm{nM}$ Fe and 0.07 to $2.84 \mathrm{nM} \mathrm{Zn} \mathrm{(Table} \mathrm{1).} \mathrm{The} \mathrm{central} \mathrm{Cali-}$ fornia experiments had some of lowest initial concentrations of dissolved $\mathrm{Fe}$ and $\mathrm{Zn}$ measured in this study ( 0.03 to $0.10 \mathrm{nM} \mathrm{Fe}$ and 0.07 to $0.2 \mathrm{nM} \mathrm{Zn)}$ ). Many of the highest initial concentrations of dissolved Fe were measured in the eastern tropical Pacific experiments ( 0.10 to $0.30 \mathrm{nM} \mathrm{Fe}$ ) and the highest initial concentrations of dissolved $\mathrm{Zn}$ were measured in the Southern Ocean experiments.

\section{California upwelling region}

$$
\mathrm{Si}(\mathrm{OH})_{4} \text { and } \mathrm{NO}_{3}{ }^{-} \text {uptake kinetics }
$$

Figs. $3 \& 4$ show $\mathrm{Si}(\mathrm{OH})_{4}$ and $\mathrm{NO}_{3}{ }^{-}$kinetic curves measured in 3 experiments conducted in waters off California, and Tables 3 \& 4 summarize the kinetics parameters calculated from the curve fits shown in the figures. Enrichments included 2 controls, $1 \mathrm{Zn}$ addition, $1 \mathrm{Fe}$ addition and $1 \mathrm{Fe}+\mathrm{Zn}$ addition (Table 2). Fe addition significantly increased $\mathrm{Si} V_{\max }$ in the Big Sur and Pt Arena experiments by 2.4 and 2.8 times, respectively, and significantly decreased $\mathrm{Si} V_{\max }$ in the $\mathrm{Pt}$ Conception experiment, to $59 \%$ of the control value (Fig. 3, Table 3). Fe addition significantly increased $\mathrm{NO}_{3}{ }^{-} V_{\max }$ in all 3 experiments off California, by 2.1 to 2.7 times (Fig. 4, Table 3).

$\mathrm{Zn}$ addition alone had mixed effects on $\mathrm{Si}$ and $\mathrm{NO}_{3}{ }^{-}$ $V_{\max }$. Zn addition significantly increased Si $V_{\max }$ by 3.2 times at the Big Sur site (Fig. 3, Table 3). This was the only experiment off California in which $\mathrm{Zn}$ addition alone had a significant effect on $\mathrm{Si} V_{\max }$. Zn addition had opposing effects on $\mathrm{NO}_{3}^{-} V_{\max }$ in California waters. In the Big Sur experiment, Zn addition significantly increased $\mathrm{NO}_{3}{ }^{-} V_{\max }$ by 1.8 times, while in the $\mathrm{Pt}$ Conception experiment $\mathrm{Zn}$ addition significantly de-

Table 3. Comparison of maximum potential uptake rates $\left(V_{\max }, \mathrm{d}^{-1}\right)$ for $\mathrm{Si}$ and $\mathrm{NO}_{3}{ }^{-}$in $\mathrm{Fe}$ and $\mathrm{Zn}$ enrichments in experiments conducted off California, in the Southern Ocean and in the eastern tropical Pacific. Errors are standard errors. Enrichments in which $V_{\max }$ values differed significantly from control values are printed in bold (2-tailed $t$-test, $\left.\alpha<0.05\right)$. In the Southern Ocean experiments, statistical comparisons of $\mathrm{Si} V_{\max }$ in the $\mathrm{Zn}$ and $\mathrm{Fe}+\mathrm{Zn}$ enrichments could not be done because measurements were not replicated $(\mathrm{n}=1)$. n: number of data points used to estimate $V_{\max i}$-: enrichment and/or measurement was not done

\begin{tabular}{|c|c|c|c|c|c|c|c|c|}
\hline \multirow{2}{*}{$\begin{array}{l}\text { Cruise } \\
\quad \text { Experiment }\end{array}$} & \multirow[b]{2}{*}{ Control } & \multirow{2}{*}{$\overline{\mathrm{Zn}} \mathrm{Si}$} & \multirow{2}{*}{$V_{\max }$} & \multirow[b]{2}{*}{$\mathrm{Fe}+\mathrm{Zn}$} & \multirow[b]{2}{*}{ Control } & \multirow{2}{*}{${ }_{\mathrm{Zn}} \mathrm{NO}_{3}^{-}$} & \multirow{2}{*}{$V_{\max } \frac{}{\mathrm{Fe}}$} & \multirow[b]{2}{*}{$\mathrm{Fe}+\mathrm{Zn}$} \\
\hline & & & & & & & & \\
\hline \multicolumn{9}{|l|}{ California } \\
\hline Big Sur & $\begin{array}{c}0.408 \pm 0.024 \\
(\mathrm{n}=7)\end{array}$ & $\begin{array}{c}1.296 \pm 0.072 \\
(n=8)\end{array}$ & $\begin{array}{c}0.960 \pm 0.072 \\
(n=8)\end{array}$ & - & $\begin{array}{c}0.288 \pm 0.024 \\
(\mathrm{n}=7)\end{array}$ & $\begin{array}{c}0.528 \pm 0.024 \\
(n=7)\end{array}$ & $\begin{array}{c}0.696 \pm 0.048 \\
(n=7)\end{array}$ & - \\
\hline Pt Arena & $\begin{array}{c}0.233 \pm 0.006 \\
(\mathrm{n}=16)\end{array}$ & $\begin{array}{c}0.242 \pm 0.007 \\
(\mathrm{n}=8)\end{array}$ & $\begin{array}{c}0.663 \pm 0.041 \\
(n=8)\end{array}$ & $\begin{array}{c}0.757 \pm 0.029 \\
(n=8)\end{array}$ & $\begin{array}{c}0.204 \pm 0.010 \\
(\mathrm{n}=11)\end{array}$ & $\begin{array}{c}0.210 \pm 0.008 \\
(\mathrm{n}=5)\end{array}$ & $\begin{array}{c}0.560 \pm 0.042 \\
(n=6)\end{array}$ & $\begin{array}{c}0.582 \pm 0.021 \\
(\mathrm{n}=6)\end{array}$ \\
\hline Pt Conception & $\begin{array}{c}0.379 \pm 0.028 \\
(\mathrm{n}=16)\end{array}$ & $\begin{array}{c}0.353 \pm 0.052 \\
(\mathrm{n}=8)\end{array}$ & $\begin{array}{c}0.225 \pm 0.012 \\
(n=7)\end{array}$ & $\begin{array}{c}0.242 \pm 0.020 \\
(n=8)\end{array}$ & $\begin{array}{c}0.180 \pm 0.012 \\
(\mathrm{n}=6)\end{array}$ & $\begin{array}{c}0.098 \pm 0.002 \\
(n=6)\end{array}$ & $\begin{array}{c}0.372 \pm 0.018 \\
(n=7)\end{array}$ & $\begin{array}{c}0.675 \pm 0.071 \\
(n=7)\end{array}$ \\
\hline \multicolumn{9}{|l|}{ Southern Ocean } \\
\hline Expt 1 & $\begin{array}{c}0.137 \pm 0.010 \\
(\mathrm{n}=2)\end{array}$ & 0.157 & $\begin{array}{c}0.246 \pm 0.007 \\
(n=3)\end{array}$ & 0.287 & - & - & - & - \\
\hline Expt 2 & $\begin{array}{c}0.340 \pm 0.008 \\
(\mathrm{n}=2)\end{array}$ & 0.359 & $\begin{array}{c}0.410 \pm 0.004 \\
(n=4)\end{array}$ & 0.459 & - & - & - & - \\
\hline Expt 3 & $\begin{array}{c}0.150 \pm 0.018 \\
(\mathrm{n}=2)\end{array}$ & 0.198 & $\begin{array}{c}0.357 \pm 0.004 \\
(n=2)\end{array}$ & 0.353 & - & - & - & - \\
\hline Expt 4 & $\begin{array}{c}0.137 \pm 0.001 \\
(\mathrm{n}=2)\end{array}$ & 0.148 & $\begin{array}{c}0.180 \pm 0.005 \\
(\mathrm{n}=4)\end{array}$ & 0.198 & - & - & - & - \\
\hline \multicolumn{9}{|c|}{ Eastern tropical Pacific } \\
\hline Costa Rica & $\begin{array}{c}0.699 \pm 0.057 \\
(\mathrm{n}=19)\end{array}$ & $\begin{array}{c}0.758 \pm 0.038 \\
(\mathrm{n}=17)\end{array}$ & $\begin{array}{c}1.158 \pm 0.103 \\
(n=14)\end{array}$ & $\begin{array}{c}1.397 \pm 0.202 \\
(n=19)\end{array}$ & $\begin{array}{c}0.109 \pm 0.010 \\
(\mathrm{n}=12)\end{array}$ & $\begin{array}{c}0.025 \pm 0.002 \\
(n=11)\end{array}$ & $\begin{array}{c}0.386 \pm 0.082 \\
(n=17)\end{array}$ & $\begin{array}{c}0.600 \pm 0.041 \\
(n=14)\end{array}$ \\
\hline Humboldt & $\begin{array}{c}0.529 \pm 0.073 \\
(\mathrm{n}=9)\end{array}$ & - & $\begin{array}{c}0.862 \pm 0.098 \\
(n=9)\end{array}$ & - & $\begin{array}{c}0.103 \pm 0.014 \\
(\mathrm{n}=9)\end{array}$ & - & $\begin{array}{c}0.261 \pm 0.009 \\
(n=9)\end{array}$ & - \\
\hline Peru & $\begin{array}{c}0.537 \pm 0.021 \\
(\mathrm{n}=9)\end{array}$ & - & $\begin{array}{c}0.373 \pm 0.027 \\
(n=9)\end{array}$ & - & $\begin{array}{c}0.299 \pm 0.015 \\
(\mathrm{n}=9)\end{array}$ & - & $\begin{array}{c}0.759 \pm 0.117 \\
(n=9)\end{array}$ & - \\
\hline
\end{tabular}



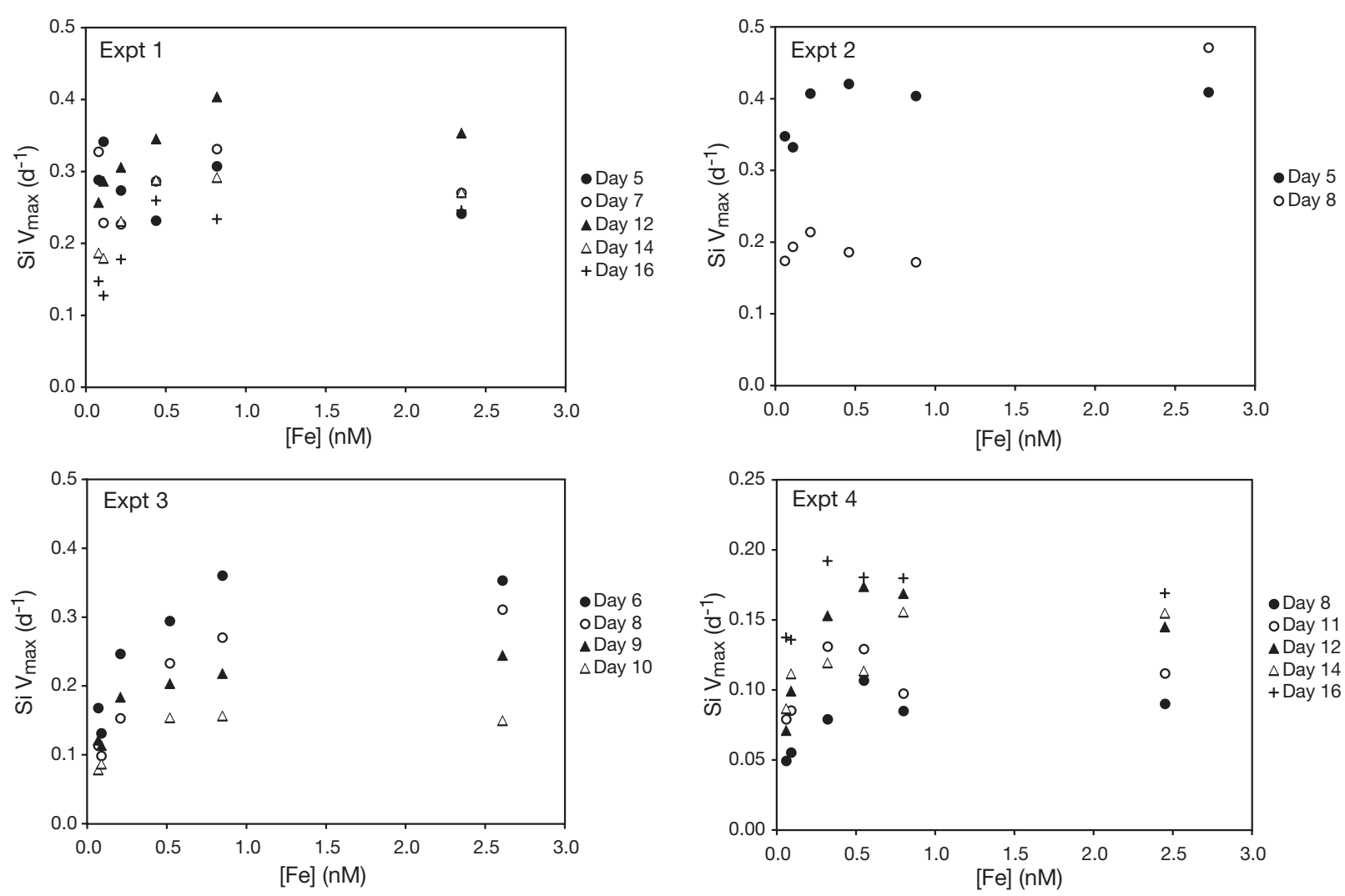

Fig. 2. Maximum potential uptake rate of $\mathrm{Si}\left(\mathrm{Si} V_{\max }\right)$ plotted as a function of dissolved Fe concentration 5 to $16 \mathrm{~d}$ after Fe addition in 4 enrichment experiments conducted in the Southern Ocean. Symbols indicate days since Fe addition. Note the different scale for Si $V_{\max }$ in Expt 4 (lower right panel)

creased $\mathrm{NO}_{3}{ }^{-} V_{\max }$ to $54 \%$ of the control value (Fig. 4, Table 3). Combined enrichments with $\mathrm{Fe}$ and $\mathrm{Zn}(\mathrm{Fe}+$ $\mathrm{Zn})$ were conducted at the Pt Arena and Pt Conception locations. The effect of $\mathrm{Fe}+\mathrm{Zn}$ additions was similar to the effect of Fe addition alone at both locations. Fe + Zn significantly increased Si $V_{\max }$ at the Pt Arena site by 3.2 times, and significantly decreased $\mathrm{Si} V_{\max }$ at the Pt Conception site to $64 \%$ of the control value (Fig. 3, Table 3). $\mathrm{NO}_{3}{ }^{-} V_{\max }$ increased by 2.8 and 3.7 times after $\mathrm{Fe}+\mathrm{Zn}$ addition at the Pt Arena and Pt Conception locations, respectively (Fig. 4, Table 3).

$\mathrm{Fe}$ and/or $\mathrm{Zn}$ additions had significant a effect on the half-saturation constant for $\mathrm{Si}(\mathrm{OH})_{4}$ uptake $\left(\mathrm{Si} K_{\mathrm{s}}\right)$ in 2 experiments conducted in waters off California, but the effect varied by location. In the Pt Arena experiment, enrichments with added $\mathrm{Fe}(\mathrm{Fe}, \mathrm{Fe}+\mathrm{Zn})$ had 3.6 and 3.8 times higher $\mathrm{Si} K_{\mathrm{s}}$ values, respectively, relative to controls (Fig. 3, Table 4). In the Big Sur experiment, the Si $K_{\mathrm{s}}$ value in the $\mathrm{Zn}$ addition was $39 \%$ of the control value (Fig. 3, Table 4). The effect of Fe, Zn and Fe $+\mathrm{Zn}$ additions on $\mathrm{NO}_{3}{ }^{-} K_{\mathrm{s}}$ values could not be examined in the experiments off California because ambient $\mathrm{NO}_{3}{ }^{-}$values were still saturating $(>3.5 \mu \mathrm{M})$ in the con- trol and $\mathrm{Zn}$ treatments at the time the kinetic experiments were conducted. It was possible to determine $\mathrm{NO}_{3}{ }^{-} K_{\mathrm{s}}$ in only 2 experiments, and only in enrichments with added $\mathrm{Fe}(\mathrm{Fe}, \mathrm{Fe}+\mathrm{Zn})$, as $\mathrm{NO}_{3}{ }^{-}$concentrations in these enrichments were low enough at the time of sampling to limit uptake $(\sim 0.1 \mu \mathrm{M})$. These values are reported in Table 4.

$\mathrm{Si}(\mathrm{OH})_{4}: \mathrm{NO}_{3}{ }^{-}$drawdown and $\mathrm{Si}(\mathrm{OH})_{4}: \mathrm{NO}_{3}{ }^{-} V_{\text {max }}$ ratios

We sought to compare the effect of $\mathrm{Fe}$ and $\mathrm{Zn}$ addition on $\mathrm{Si}(\mathrm{OH})_{4}: \mathrm{NO}_{3}{ }^{-}$drawdown ratios, calculated from changes in nutrient concentrations over time, with the effect of $\mathrm{Fe}$ and $\mathrm{Zn}$ on $\mathrm{Si}(\mathrm{OH})_{4}: \mathrm{NO}_{3}{ }^{-} V_{\max }$ ratios (i.e. the ratio of $\mathrm{Si} V_{\max }$ to $\mathrm{NO}_{3}{ }^{-} V_{\max }$ in order to determine whether changes in nutrient drawdown ratios could result from changes in nutrient uptake kinetics. Fe addition decreased $\mathrm{Si}(\mathrm{OH})_{4}: \mathrm{NO}_{3}{ }^{-}$drawdown ratios in both the Big Sur and Pt Conception experiments off California (Table 5). Fe addition also decreased the $\mathrm{Si}(\mathrm{OH})_{4}: \mathrm{NO}_{3}{ }^{-} V_{\max }$ ratio in the Pt Conception experiment. In the Pt Arena experiment, $\mathrm{Si}(\mathrm{OH})_{4}$ and $\mathrm{NO}_{3}{ }^{-}$ 
concentrations were near the detection limit in the $\mathrm{Fe}$ and $\mathrm{Fe}+\mathrm{Zn}$ enrichments by the time kinetic experiments were done, and thus $\mathrm{Si}(\mathrm{OH})_{4}: \mathrm{NO}_{3}{ }^{-}$drawdown ratios in these enrichments represent the initial ratio of $\mathrm{Si}(\mathrm{OH})_{4}$ concentration to $\mathrm{NO}_{3}{ }^{-}$concentration in the water collected for this experiment $(0.4$, Table 1$)$. The $\mathrm{Si}(\mathrm{OH})_{4}: \mathrm{NO}_{3}{ }^{-}$uptake ratio in the Pt Arena experiment, measured immediately after water collection using tracers, was somewhat high (1.5) but the final drawdown ratios calculated in the controls were very close to the value reported for trace-metal replete diatoms in culture ( 1, Brzezinski 1985). Similarly, $\mathrm{Si}(\mathrm{OH})_{4}: \mathrm{NO}_{3}{ }^{-}$ $V_{\max }$ ratios in this experiment were $\sim 1$ in the controls and did not change significantly with either Fe or Zn addition. Contrary to the effect of Fe in the Big Sur and $\mathrm{Pt}$ Conception experiments, $\mathrm{Zn}$ addition increased $\mathrm{Si}(\mathrm{OH})_{4}: \mathrm{NO}_{3}{ }^{-}$drawdown and $\mathrm{Si}(\mathrm{OH})_{4}: \mathrm{NO}_{3}{ }^{-} V_{\text {max }}$ ratios. In the Big Sur enrichment, $\mathrm{Si}(\mathrm{OH})_{4}: \mathrm{NO}_{3}{ }^{-}$drawdown and $V_{\max }$ ratios increased due to $\mathrm{Zn}$-stimulated increases in $\mathrm{Si}(\mathrm{OH})_{4}$ drawdown and $\mathrm{Si} V_{\max }$ (Fig. 3, Table 3). In the Pt Conception experiment, the ratios increased due to $\mathrm{Zn}$-stimulated declines in $\mathrm{NO}_{3}{ }^{-}$drawdown and $\mathrm{NO}_{3}{ }^{-}$ $V_{\max }$ (Fig. 4, Table 3).
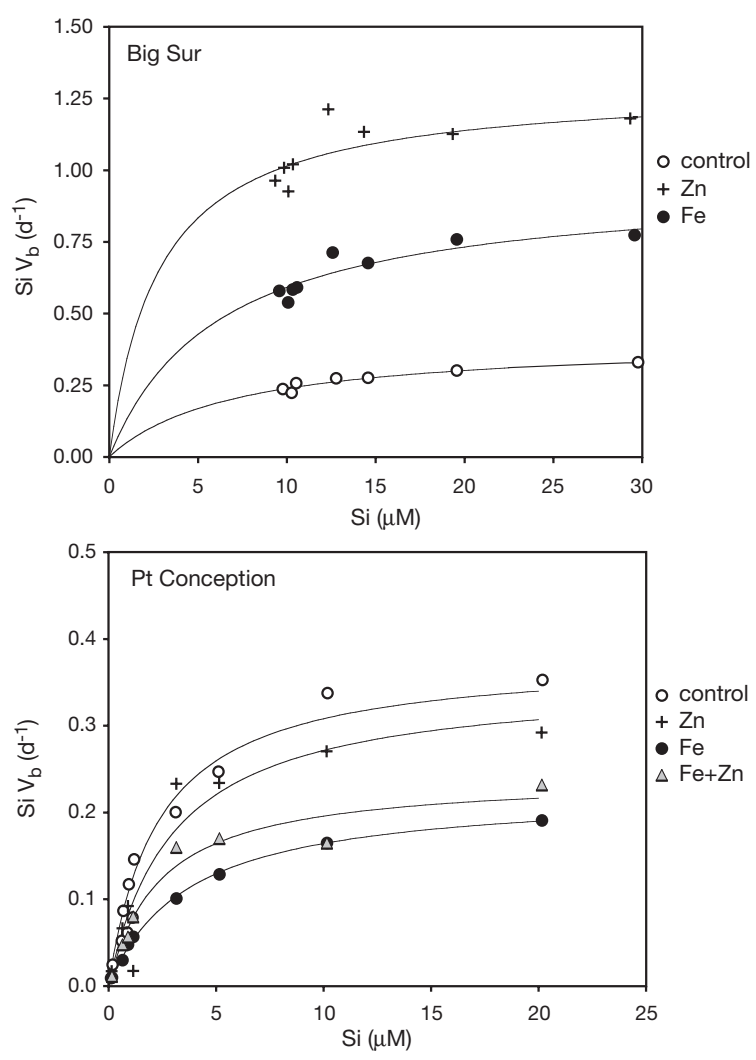

Phytoplankton species composition

Diatoms were the dominant taxonomic group in all the enrichments in the Pt Arena and Pt Conception experiments (Table 6). The most abundant diatoms included Chaetoceros spp., as well as Pseudo-nitzschia spp. and small $(<20 \mu \mathrm{m})$ pennate diatoms. In both experiments, total cell numbers were higher in the $\mathrm{Fe}, \mathrm{Zn}$ and $\mathrm{Fe}+\mathrm{Zn}$ enrichments than in the controls, and were greatest in the combined $\mathrm{Fe}+\mathrm{Zn}$ additions. In the $\mathrm{Pt}$ Arena experiment, Fe and $\mathrm{Zn}$ addition led to similar increases in relative proportion of Chaetoceros spp., from $67 \%$ in the controls to 80 to $83 \%$ in the metal additions, and to slight decreases in the relative abundance of Pseudo-nitzschia spp., from 13 to $4-12 \%$. This produced a higher proportion of centric diatoms in the $\mathrm{Fe}$ and $\mathrm{Zn}$ enrichments relative the controls: 79 to $83 \%$ versus $65 \%$. In the Pt Conception experiment, Chaetoceros spp. and Pseudonitzschia spp. were again the dominant phytoplankton groups. Rhizosolenia spp. were also present in this experiment, accounting for 0.3 to $4 \%$ of total cells. The large size and surface area of Rhizosolenia
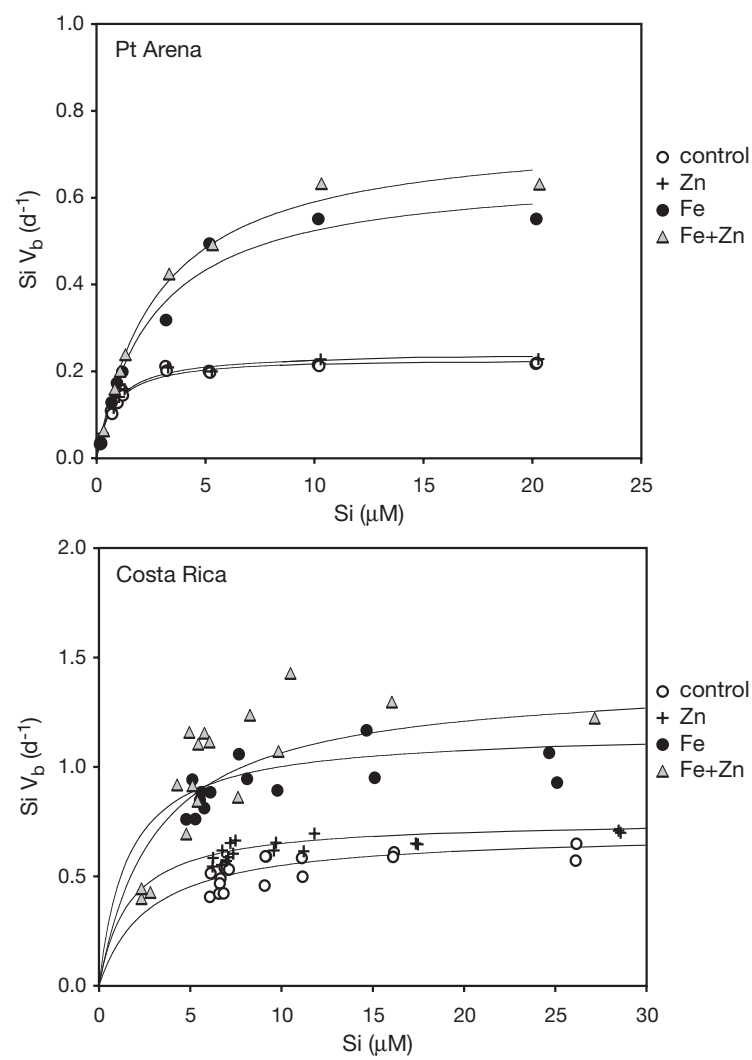

Fig. 3. Biomass-specific Si uptake rates ( $\mathrm{Si} V_{\mathrm{b}}$ ) plotted as a function of dissolved Si concentration (i.e. Si uptake kinetics) in 4 enrichment experiments in waters off California (Big Sur, Pt Arena, Pt Conception) and the eastern tropical Pacific (Costa Rica). Legend labels indicate trace-metal enrichment: control (open circle), Zn addition (plus), Fe addition (closed circle), combined Fe $+\mathrm{Zn}$ addition (shaded triangle). Note the different scales in each panel 

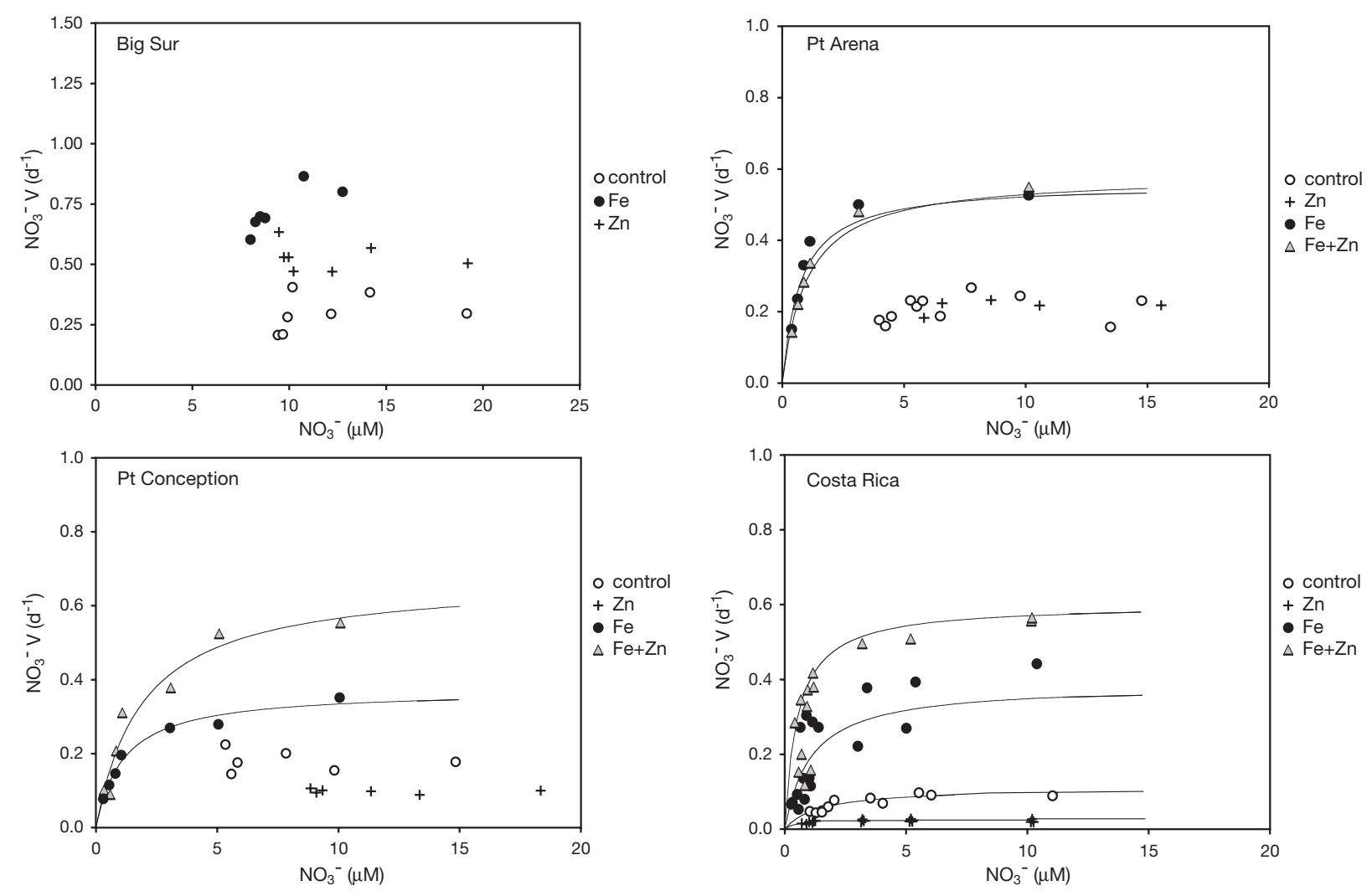

Fig. 4. See Fig. 3 legend for details, except this is for $\mathrm{NO}_{3}^{-}$(i.e. $\mathrm{NO}_{3}^{-}$uptake kinetics). Note the different scale for biomass-specific $\mathrm{NO}_{3}{ }^{-}$uptake $\left(\mathrm{NO}_{3}{ }^{-} \mathrm{V}\right)$ in the Big Sur experiment (upper left panel)

spp. diatoms means they can contribute significantly to silicon uptake even at abundances as low as $10 \mathrm{ml}^{-1}$ (Franck et al. unpubl.). In the Pt Conception experiment, Fe addition alone and in combination with $\mathrm{Zn}$ increased the relative abundance of Chaetoceros spp. cells and decreased the relative abundance of Pseudo-nitzschia spp. cells, again resulting in an higher percentage of centric diatoms: 58 to $63 \%$ of total cells in the control and $\mathrm{Zn}$ additions and 69 to $72 \%$ in the $\mathrm{Fe}$ and $\mathrm{Fe}+\mathrm{Zn}$ additions. The relative abundance of Rhizosolenia spp. cells also decreased after $\mathrm{Fe}$ addition, from 1 to $4 \%$ of total cells in the control and $\mathrm{Zn}$ additions to 0.3 to $1 \%$ in the $\mathrm{Fe}$ and $\mathrm{Fe}+\mathrm{Zn}$ additions.

Table 4. Comparison of half-satuation constants $\left(K_{\mathrm{s}}, \mu \mathrm{M}\right)$ for $\mathrm{Si}$ and $\mathrm{NO}_{3}{ }^{-}$uptake in $\mathrm{Fe}$ and $\mathrm{Zn}$ enrichments in experiments conducted off California and in the eastern tropical Pacific. Errors are standard errors. Enrichments in which $K_{\mathrm{s}}$ values differed significantly from control values are printed in bold ( $t$-test, $\alpha<0.05$ ). n: number of data points used to estimate $K_{\mathrm{s} i}-:$ enrichment not done; ${ }^{*}{ }^{*} K_{\mathrm{s}}$ could not be estimated $\left(\mathrm{NO}_{3}{ }^{-}\right.$concentrations were saturating)

\begin{tabular}{|c|c|c|c|c|c|c|c|c|}
\hline \multirow{2}{*}{$\begin{array}{l}\text { Cruise } \\
\text { Experiment }\end{array}$} & \multirow[b]{2}{*}{ Control } & Si:NO & \multirow[b]{2}{*}{$\mathrm{Fe}$} & \multirow[b]{2}{*}{$\mathrm{Fe}+\mathrm{Zn}$} & \multirow[b]{2}{*}{ Control } & \multirow{2}{*}{${ }_{\mathrm{Zn}} \mathrm{NO}_{3}^{-}$} & \multirow[b]{2}{*}{$\mathrm{Fe}$} & \multirow[b]{2}{*}{$\mathrm{Fe}+\mathrm{Zn}$} \\
\hline & & $\mathrm{Zn}$ & & & & & & \\
\hline \multicolumn{9}{|l|}{ California } \\
\hline Big Sur & $\begin{array}{c}7.11 \pm 1.04 \\
(\mathrm{n}=7)\end{array}$ & $\begin{array}{c}2.78 \pm 0.87 \\
(\mathrm{n}=8)\end{array}$ & $\begin{array}{c}6.24 \pm 1.04 \\
(\mathrm{n}=8)\end{array}$ & - & ${ }^{* *}$ & $* *$ & $* *$ & - \\
\hline Pt Arena & $\begin{array}{c}0.75 \pm 0.07 \\
(\mathrm{n}=16)\end{array}$ & $\begin{array}{c}0.78 \pm 0.09 \\
(\mathrm{n}=8)\end{array}$ & $\begin{array}{c}2.66 \pm 0.49 \\
(\mathrm{n}=8)\end{array}$ & $\begin{array}{c}2.83 \pm 0.31 \\
(\mathrm{n}=8)\end{array}$ & $* *$ & $* *$ & $\begin{array}{c}0.74 \pm 0.17 \\
(\mathrm{n}=6)\end{array}$ & $\begin{array}{c}1.02 \pm 0.11 \\
(\mathrm{n}=6)\end{array}$ \\
\hline Pt Conception & $\begin{array}{c}2.31 \pm 0.54 \\
(\mathrm{n}=16)\end{array}$ & $\begin{array}{c}3.01 \pm 1.29 \\
(\mathrm{n}=8)\end{array}$ & $\begin{array}{c}3.71 \pm 0.76 \\
(\mathrm{n}=7)\end{array}$ & $\begin{array}{c}2.37 \pm 0.60 \\
(\mathrm{n}=8)\end{array}$ & $* *$ & $* *$ & $\begin{array}{c}1.14 \pm 0.17 \\
(\mathrm{n}=7)\end{array}$ & $\begin{array}{c}1.93 \pm 0.55 \\
(\mathrm{n}=7)\end{array}$ \\
\hline \multicolumn{9}{|c|}{ Eastern tropical Pacific } \\
\hline Costa Rica & $\begin{array}{c}2.73 \pm 0.92 \\
(\mathrm{n}=19)\end{array}$ & $\begin{array}{c}1.67 \pm 0.50 \\
(\mathrm{n}=17)\end{array}$ & $\begin{array}{c}1.57 \pm 0.74 \\
(\mathrm{n}=14)\end{array}$ & $\begin{array}{c}3.13 \pm 1.51 \\
(\mathrm{n}=19)\end{array}$ & $\begin{array}{c}1.42 \pm 0.39 \\
(\mathrm{n}=12)\end{array}$ & $\begin{array}{c}0.46 \pm 0.19 \\
(n=11)\end{array}$ & $\begin{array}{c}1.09 \pm 0.59 \\
(\mathrm{n}=17)\end{array}$ & $\begin{array}{c}0.53 \pm 0.14 \\
(\mathrm{n}=14)\end{array}$ \\
\hline
\end{tabular}


Table 5. Si: $\mathrm{NO}_{3}{ }^{-}$uptake ratios in initial waters and comparison of $\mathrm{Si}: \mathrm{NO}_{3}{ }^{-}$drawdown and $V_{\max }$ ratios in Fe and $\mathrm{Zn}$ enrichments in experiments off California and in the eastern tropical Pacific. Errors are standard errors. Enrichments in which $V_{\text {max }}$ ratios differed significantly from control ratios are printed in bold ( $t$-test, $\alpha<0.001$ ). Si: $\mathrm{NO}_{3}{ }^{-}$drawdown ratios in parentheses represent initial dissolved $\mathrm{Si}: \mathrm{NO}_{3}{ }^{-}$ratios (see text). -: measurement/enrichment not done

\begin{tabular}{|c|c|c|c|c|c|c|c|c|c|}
\hline \multirow{2}{*}{$\begin{array}{l}\text { Cruise } \\
\quad \text { Experiment }\end{array}$} & \multirow{2}{*}{$\mathrm{Si}: \mathrm{NO}_{3}{ }^{-}$uptake } & \multicolumn{4}{|c|}{$-\mathrm{Si}: \mathrm{NO}_{3}{ }^{-}$drawdown } & \multirow[b]{2}{*}{ Control } & \multirow{2}{*}{$\begin{array}{c}-\mathrm{Si}: \mathrm{NO}_{3}{ }^{-} \\
\mathrm{Zn}\end{array}$} & \multirow{2}{*}{$V_{\max }$} & \multirow[b]{2}{*}{$\mathrm{Fe}+\mathrm{Zn}$} \\
\hline & & Control & $\mathrm{Zn}$ & $\mathrm{Fe}$ & $\mathrm{Fe}+\mathrm{Zn}$ & & & & \\
\hline \multicolumn{10}{|l|}{ California } \\
\hline Big Sur & - & 1.7 & 1.9 & 1.2 & - & $1.4 \pm 0.0$ & $2.5 \pm 0.1$ & $1.4 \pm 0.1$ & - \\
\hline Pt. Arena & 1.5 & 0.9 & 1.1 & $(0.4)$ & $(0.4)$ & $1.1 \pm 0.0$ & $1.2 \pm 0.0$ & $1.2 \pm 0.1$ & $1.3 \pm 0.0$ \\
\hline Pt Conception & 1.5 & 2.2 & 5.5 & 1.0 & 1.0 & $2.1 \pm 0.0$ & $3.6 \pm 0.1$ & $0.6 \pm 0.0$ & $0.4 \pm 0.1$ \\
\hline \multicolumn{10}{|c|}{ Eastern tropical Pacific } \\
\hline Costa Rica & 6.0 & 5.8 & 26.9 & 3.3 & 3.9 & $6.4 \pm 0.1$ & $30.3 \pm 0.0$ & $3.0 \pm 0.1$ & $2.3 \pm 0.2$ \\
\hline Humboldt & 5.8 & 6.1 & - & 3.4 & - & $5.1 \pm 0.1$ & - & $3.3 \pm 0.1$ & - \\
\hline Peru & 2.5 & 1.8 & - & 0.5 & - & $1.8 \pm 0.0$ & - & $0.5 \pm 0.1$ & - \\
\hline
\end{tabular}

\section{Eastern tropical Pacific}

$$
\mathrm{Si}(\mathrm{OH})_{4} \text { and } \mathrm{NO}_{3}{ }^{-} \text {uptake kinetics }\left(V_{\max }, K_{\mathrm{s}}\right)
$$

Figs. 3 \& 4 show $\mathrm{Si}(\mathrm{OH})_{4}$ and $\mathrm{NO}_{3}{ }^{-}$kinetic curves measured in 4 enrichments (controls, +1 nM Zn, +2 nM $\mathrm{Fe}_{\text {, }}+2 \mathrm{nM} \mathrm{Fe}+1 \mathrm{nM} \mathrm{Zn)}$ at the Costa Rica Upwelling Dome location; Tables 3 \& 4 summarize kinetics parameters measured at all locations. (Due to time constraints, smaller kinetic experiments measuring only $\mathrm{Si}$ $V_{\text {max }}$ and $\mathrm{NO}_{3}{ }^{-} V_{\text {max }}$ values were conducted at the Humboldt and Peru locations.) Fe addition significantly increased both $\mathrm{Si} V_{\max }$ and $\mathrm{NO}_{3}{ }^{-} V_{\max }$ in the Costa Rica experiment (Fig. 3, Table 3). Relative to controls, Si $V_{\max }$ values increased 1.7 times and $\mathrm{NO}_{3}{ }^{-}$ $V_{\max }$ values increased 3.5 times. Fe addition had a sig- nificant effect on both $\mathrm{Si} V_{\max }$ and $\mathrm{NO}_{3}{ }^{-} V_{\max }$ values in the Humboldt experiment as well, increasing $\mathrm{Si} V_{\max }$ by 1.6 times and $\mathrm{NO}_{3}{ }^{-} V_{\max }$ by 2.5 times relative to controls (Table 3 ). In the Peru experiment, Fe addition resulted in a $31 \%$ decrease in $\mathrm{Si} V_{\max }$ values relative to controls, and a small but significant $(1.2 \times)$ increase in $\mathrm{NO}_{3}{ }^{-} V_{\text {max }}$ (Table 3).

The effect of $\mathrm{Zn}$ addition on $\mathrm{Si}$ and $\mathrm{NO}_{3}{ }^{-} V_{\text {max }}$ was investigated only at the Costa Rica Upwelling Dome location. Zn addition alone had no effect on $\mathrm{Si} V_{\max }$ in this experiment, and significantly decreased $\mathrm{NO}_{3}{ }^{-} V_{\max }$ by $80 \%$ (Figs. $3 \& 4$, Table 3 ). Combined additions of $\mathrm{Fe}+\mathrm{Zn}$ significantly increased both Si $V_{\max }(2.0 \times)$ and $\mathrm{NO}_{3}^{-} V_{\max }(5.5 \times)$ relative to controls. The effect of combined $\mathrm{Fe}+\mathrm{Zn}$ addition on $\mathrm{Si} V_{\max }$ was similar to the effect of $\mathrm{Fe}$ addition alone at this site, but the effect

Table 6. Microplankton cell counts in enrichment experiments conducted off California. Errors are standard errors from replicate field counts. Rare: $<20$ cells per 400 observed $_{i}-$ : no cells of that type observed

\begin{tabular}{|c|c|c|c|c|c|c|c|c|}
\hline \multirow{2}{*}{$\begin{array}{l}\text { Phytoplankton } \\
\text { taxa }\end{array}$} & \multicolumn{4}{|c|}{ Pt Arena } & \multirow[b]{2}{*}{$\begin{array}{c}\text { Control } \\
\left(\text { cells ml } l^{-1}\right)\end{array}$} & \multirow{2}{*}{$\begin{array}{c}\text { Pt Conc } \\
\mathrm{Zn} \\
\left(\text { cells ml }{ }^{-1}\right)\end{array}$} & \multirow[b]{2}{*}{$\begin{array}{l}\text { Fe } \\
\left(\text { cells } \mathrm{ml}^{-1} \text { ) }\right.\end{array}$} & \multirow[b]{2}{*}{$\begin{array}{c}\mathrm{Fe}+\mathrm{Zn} \\
\left(\text { cells } \mathrm{ml}^{-1}\right)\end{array}$} \\
\hline & $\begin{array}{l}\text { Control } \\
\left(\text { cells ml }{ }^{-1}\right)\end{array}$ & $\begin{array}{c}\mathrm{Zn} \\
\text { (cells ml-1) }\end{array}$ & $\begin{array}{c}\mathrm{Fe} \\
\left(\text { cells } \mathrm{ml}^{-1} \text { ) }\right.\end{array}$ & $\begin{array}{c}\mathrm{Fe}+\mathrm{Zn} \\
\left(\text { cells } \mathrm{ml}^{-1}\right)\end{array}$ & & & & \\
\hline \multicolumn{9}{|l|}{ Diatoms } \\
\hline Centrics & $1286 \pm 192$ & $6514 \pm 503$ & $3866 \pm 385$ & $12142 \pm 4726$ & $2805 \pm 1320$ & $3897 \pm 725$ & $11025 \pm 948$ & $14625 \pm 2066$ \\
\hline Chaetoceros spp. & $1261 \pm 194$ & $6458 \pm 513$ & $3721 \pm 391$ & $11732 \pm 4711$ & $2503 \pm 1249$ & $3534 \pm 772$ & $10615 \pm 818$ & $13855 \pm 2085$ \\
\hline Rhizosolenia spp. & Rare & Rare & Rare & Rare & $59 \pm 4$ & $59 \pm 11$ & $107 \pm 7$ & $57 \pm 5$ \\
\hline Coscinodiscineae & Rare & Rare & Rare & Rare & Rare & Rare & Rare & Rare \\
\hline Corethron spp. & Rare & Rare & Rare & Rare & Rare & Rare & Rare & Rare \\
\hline Pennates & $621 \pm 113$ & $1564 \pm 111$ & $950 \pm 163$ & $2421 \pm 590$ & $2000 \pm 363$ & $2221 \pm 360$ & $4991 \pm 552$ & $5413 \pm 820$ \\
\hline$<20 \mu \mathrm{m}$ pennates & $49 \pm 21$ & $56 \pm 11$ & $156 \pm 83$ & $596 \pm 275$ & $134 \pm 106$ & $154 \pm 56$ & $894 \pm 223$ & $670 \pm 217$ \\
\hline Pseudo-nitzschia spp & p. $240 \pm 50$ & $950 \pm 176$ & $190 \pm 82$ & $633 \pm 203$ & $1318 \pm 197$ & $1592 \pm 337$ & $931 \pm 358$ & $2657 \pm 624$ \\
\hline Fragilariopsis spp. & Rare & Rare & Rare & Rare & - & - & Rare & - \\
\hline Thalassiothrix spp. & Rare & $125 \pm 21$ & Rare & Rare & Rare & - & - & Rare \\
\hline Thalassionema spp. & Rare & Rare & - & - & Rare & - & Rare & Rare \\
\hline Other cells & $8 \pm 5$ & $34 \pm 24$ & $123 \pm 94$ & $112 \pm 76$ & $45 \pm 45$ & $70 \pm 36$ & $74 \pm 47$ & $149 \pm 79$ \\
\hline Dinoflagellates & Rare & Rare & Rare & - & Rare & Rare & Rare & Rare \\
\hline Silicoflagellates & Rare & - & - & - & Rare & Rare & Rare & - \\
\hline Other flagellates & Rare & Rare & Rare & Rare & Rare & Rare & Rare & Rare \\
\hline Total cells & $1912 \pm 251$ & $8112 \pm 578$ & $4872 \pm 442$ & $14675 \pm 5294$ & $5632 \pm 315$ & $6187 \pm 1046$ & $16004 \pm 890$ & $20187 \pm 2388$ \\
\hline
\end{tabular}


on $\mathrm{NO}_{3}{ }^{-} V_{\text {max }}$ was much stronger than that for Fe addition.

$\mathrm{Si}$ and $\mathrm{NO}_{3}{ }^{-} K_{\mathrm{s}}$ values were measured only at the Costa Rica Upwelling Dome location. None of the trace-metal additions had significant effects on Si $K_{\mathrm{s}}$ values in this experiment (Fig. 3, Table 4). Additions with $\mathrm{Zn}(\mathrm{Zn}$ and $\mathrm{Fe}+\mathrm{Zn})$ significantly decreased $\mathrm{NO}_{3}{ }^{-}$ $K_{\mathrm{s}}$, by $68 \%$ for $\mathrm{Zn}$ alone and by $63 \%$ for combined $\mathrm{Fe}+$ Zn (Fig. 4, Table 4).

\section{$\mathrm{Si}(\mathrm{OH})_{4}: \mathrm{NO}_{3}{ }^{-}$drawdown ratios and $V_{\max }$ ratios}

In situ $\mathrm{Si}(\mathrm{OH})_{4}: \mathrm{NO}_{3}{ }^{-}$uptake ratios-measured with tracers at the beginning of the experiments-agreed well with $\mathrm{Si}(\mathrm{OH})_{4}: \mathrm{NO}_{3}{ }^{-}$drawdown ratios in the controls, which were calculated at the end of the experiments from changes in $\mathrm{Si}(\mathrm{OH})_{4}$ and $\mathrm{NO}_{3}{ }^{-}$after 3 to $6 \mathrm{~d}$ incubation ( 2.5 to 6.0 vs 1.8 to 6.1 , Table 5 ). Both ratios were much higher than the mean value of $\sim 1$ reported for trace-metal replete diatom cultures (Brzezinski 1985), although the values fall within the range of $\mathrm{Si}(\mathrm{OH})_{4}: \mathrm{NO}_{3}{ }^{-}$uptake ratios measured in low-Fe waters in the Southern Ocean (1.5 to 8, Franck et al. 2000).

$\mathrm{Fe}$ addition ( $\mathrm{Fe}$ and $\mathrm{Fe}+\mathrm{Zn}$ ) resulted in lower $\mathrm{Si}(\mathrm{OH})_{4}: \mathrm{NO}_{3}{ }^{-}$drawdown ratios relative to in situ $\mathrm{Si}(\mathrm{OH})_{4}: \mathrm{NO}_{3}{ }^{-}$uptake ratios and $\mathrm{Si}(\mathrm{OH})_{4}: \mathrm{NO}_{3}{ }^{-}$drawdown ratios in both the controls and $\mathrm{Zn}$ additions (Table 5). This was true for all 3 experiments in the eastern tropical Pacific. $\mathrm{Si}(\mathrm{OH})_{4}: \mathrm{NO}_{3}{ }^{-} V_{\max }$ ratios were also significantly lower in $\mathrm{Fe}$ and $\mathrm{Fe}+\mathrm{Zn}$ additions relative to controls at all 3 locations (Table 5). $\mathrm{Si}(\mathrm{OH})_{4}$ :
$\mathrm{NO}_{3}^{-} V_{\text {max }}$ ratios, measured with tracers, were very similar to $\mathrm{Si}(\mathrm{OH})_{4}: \mathrm{NO}_{3}{ }^{-}$drawdown ratios calculated from changes in $\mathrm{Si}(\mathrm{OH})_{4}$ and $\mathrm{NO}_{3}{ }^{-}$concentrations over the course of the experiment. With the exception of the $\mathrm{Fe}+\mathrm{Zn}$ treatment at the Costa Rica site, these 2 independent measurements varied by $<20 \%$. At the Costa Rica and Humboldt sites, drawdown and $V_{\max }$ ratios remained high (2.3 to 3.9) even after 3 to $6 \mathrm{~d}$ incubation with $+2 \mathrm{nM}$ Fe. The effect of $\mathrm{Zn}$ addition on $\mathrm{Si}(\mathrm{OH})_{4}: \mathrm{NO}_{3}{ }^{-}$drawdown and $V_{\text {max }}$ ratios was measured only at the Costa Rica site. At this location, Zn additions led to 4.6- to 4.7-fold increases relative to controls in both drawdown and $V_{\max }$ ratios, resulting in extremely high ratios (26.9 to 30.3$)$.

\section{Phytoplankton species composition}

Total cell counts in the controls were almost an order of magnitude lower than those in the central California experiments (Table 7). In the Costa Rica Upwelling Dome experiment, $\mathrm{Fe}$ and $\mathrm{Fe}+\mathrm{Zn}$ additions substantially increased total cell numbers, to values similar to those seen in the California experiments $\left(10^{3}\right.$ to $10^{4} \mathrm{ml}^{-1}$ ). Although we did not enumerate picophytoplankton, other studies reveal that this experiment was conducted during a Prochlorococcus spp. bloom $\left(\sim 10^{4} \mathrm{ml}^{-1}\right.$, R. Kudela et al. unpubl.). Our phytoplankton counts were dominated by pennate diatoms as well as various flagellate groups, including silicoflagellates (genus Meringosphaera). Following Fe addition, the pennate diatoms accounted for most of the observed

Table 7. Microplankton cell counts in enrichment experiments conducted in the eastern tropical Pacific. Errors are standard errors from replicate field counts. Rare: $<20$ cells per 400 observed; -: no cells of that type observed

\begin{tabular}{|c|c|c|c|c|c|c|c|c|}
\hline \multirow{2}{*}{$\begin{array}{l}\text { Phytoplankton } \\
\text { taxa }\end{array}$} & \multirow[b]{2}{*}{$\begin{array}{c}\text { Control } \\
\left(\text { cells ml }{ }^{-1}\right)\end{array}$} & \multirow{2}{*}{$\begin{array}{c}\text { Costa R } \\
\mathrm{Zn} \\
\left(\text { cells ml }{ }^{-1} \text { ) }\right.\end{array}$} & \multirow{2}{*}{$\begin{array}{l}\text { ica } \frac{}{\mathrm{Fe}} \\
\left(\text { cells } \mathrm{ml}^{-1}\right)\end{array}$} & \multirow[b]{2}{*}{$\begin{array}{c}\mathrm{Fe}+\mathrm{Zn} \\
\left(\text { cells } \mathrm{ml}^{-1}\right)\end{array}$} & \multicolumn{2}{|c|}{$\longrightarrow$ Humboldt } & $\longrightarrow$ Per & \multirow{2}{*}{$\begin{array}{l}\mathrm{u} \\
\mathrm{Fe} \\
\left(\text { cells } \mathrm{ml}^{-1}\right)\end{array}$} \\
\hline & & & & & $\begin{array}{c}\text { Control } \\
\left(\text { cells ml } l^{-1}\right)\end{array}$ & $\begin{array}{c}\mathrm{Fe} \\
\left(\text { cells } \mathrm{ml}^{-1} \text { ) }\right.\end{array}$ & $\begin{array}{c}\text { Control } \\
\left(\text { cells ml } l^{-1}\right)\end{array}$ & \\
\hline \multicolumn{9}{|l|}{ Diatoms } \\
\hline Centrics & $9 \pm 5$ & $24 \pm 12$ & $31 \pm 15$ & $319 \pm 168$ & $62 \pm 13$ & $63 \pm 17$ & $59 \pm 12$ & $44 \pm 9$ \\
\hline Chaetoceros spp. & - & Rare & Rare & Rare & $51 \pm 13$ & $61 \pm 18$ & $40 \pm 12$ & $33 \pm 7$ \\
\hline Rhizosolenia spp. & - & - & - & Rare & Rare & Rare & Rare & Rare \\
\hline Coscinodiscinceae & Rare & Rare & Rare & Rare & Rare & Rare & Rare & Rare \\
\hline Corethron spp. & Rare & Rare & Rare & Rare & Rare & Rare & Rare & Rare \\
\hline Pennates & $314 \pm 31$ & $293 \pm 35$ & $885 \pm 83$ & $12163 \pm 695$ & $82 \pm 9$ & $137 \pm 13$ & $166 \pm 14$ & $92 \pm 15$ \\
\hline$<20 \mu \mathrm{m}$ pennates & $180 \pm 17$ & $192 \pm 20$ & $501 \pm 56$ & $8716 \pm 637$ & $16 \pm 4$ & $25 \pm 7$ & Rare & Rare \\
\hline Pseudo-nitzschia spp. & p. $39 \pm 7$ & $55 \pm 12$ & $134 \pm 35$ & $1213 \pm 544$ & $41 \pm 8$ & $63 \pm 7$ & $26 \pm 10$ & $27 \pm 11$ \\
\hline Fragilariopsis spp. & $37 \pm 5$ & $40 \pm 9$ & - & - & Rare & Rare & Rare & Rare \\
\hline Thalassiothrix spp. & - & - & $89 \pm 11$ & $223 \pm 98$ & - & Rare & Rare & Rare \\
\hline Thalassionema spp. & - & - & - & - & - & - & Rare & Rare \\
\hline Other cells & $127 \pm 27$ & $80 \pm 26$ & $201 \pm 58$ & $734 \pm 210$ & $23 \pm 4$ & $83 \pm 9$ & $154 \pm 43$ & $189 \pm 55$ \\
\hline Dinoflagellates & Rare & Rare & Rare & Rare & Rare & Rare & Rare & Rare \\
\hline Silicoflagellates & $38 \pm 10$ & Rare & Rare & Rare & Rare & Rare & Rare & Rare \\
\hline Other flagellates & $68 \pm 8$ & $47 \pm 12$ & $170 \pm 38$ & $670 \pm 146$ & $16 \pm 4$ & $65 \pm 9$ & $133 \pm 30$ & $171 \pm 33$ \\
\hline Total cells & $450 \pm 32$ & $386 \pm 43$ & $1117 \pm 116$ & $13217 \pm 863$ & $167 \pm 14$ & $282 \pm 24$ & $379 \pm 16$ & $325 \pm 26$ \\
\hline
\end{tabular}


increase in cells, and the relative abundance of pennates increased from $70 \%$ of total cells in the controls to 80 to $92 \%$ in the $\mathrm{Fe}$ and $\mathrm{Fe}+\mathrm{Zn}$ additions. In contrast to the Costa Rica Upwelling Dome experiment, total cell counts remained low even after Fe addition in Humboldt and Peru experiments $\left(10^{2} \mathrm{ml}^{-1}\right)$. Our counts at these locations were dominated by flagellates as well as diatoms, and the major microplankton groups included Chaetoceros spp., Pseudo-nitzschia spp., small pennates and, in the Peru experiment, colonial flagellates of the genus Dinobryon. In the Humboldt experiment, $\mathrm{Fe}$ addition resulted in decline in the relative abundance of centric diatoms, due to a decline in the percentage of Chaetoceros spp. as well as an increase in the percentage of flagellates. In the Peru experiment, Fe addition resulted in a decline in the relative abundance of pennate diatoms, due to a decrease in the percent of some of the rarer pennates, including Nitzschia spp. and Navicula spp., as well as to an increase in the abundance of flagellates.

\section{Southern Ocean}

$$
\mathrm{Si}(\mathrm{OH})_{4} \text { uptake kinetics }\left(V_{\max }\right)
$$

Two of the 4 long-term ( 8 to $16 \mathrm{~d}$ ) enrichment experiments conducted in the Southern Ocean showed marked changes in $\mathrm{Si}(\mathrm{OH})_{4}$ and $\mathrm{NO}_{3}{ }^{-}$uptake rates and phytoplankton biomass - including biogenic silica, particulate organic nitrogen and carbon and chl afollowing Fe addition (Expts 1 and 3) (Franck et al. 2000, Coale et al. 2003). In Expt $4, \mathrm{NO}_{3}{ }^{-}$uptake rates responded strongly to $\mathrm{Fe}$ addition but $\mathrm{Si}(\mathrm{OH})_{4}$ uptake rates and biogenic silica concentrations did not (Franck et al. 2000). As shown in Fig. 2, Fe addition increased $\mathrm{Si} V_{\max }$ values in all 3 of these experiments (Expts 1, 3 and 4). In most cases, the relationship between $\mathrm{Si} V_{\max }$ and dissolved Fe concentration tended to be hyperbolic, similar to the relationship observed between uptake rate and substrate concentration in kinetic experiments (e.g. Figs. 3 \& 4).

Si $V_{\max }$ values showed a clear response to increasing Fe concentrations in the experiment conducted south of the Polar Frontal Zone in austral summer (Expt 3) (Fig. 2). This was true for all $4 \mathrm{~d}$ sampled. $V_{\max }$ values were greatest in the higher ( 1 to $2 \mathrm{nM}$ ) Fe additions, and varied from 1.4 to 2.9 times those in the controls, depending on sampling date and Fe addition. Fe had the greatest stimulatory effect on Si $V_{\max }$ on Day 6 , when $V_{\max }$ values were highest, and the smallest effect at the end of the experiment on Day 10, when Si $V_{\max }$ values were lowest.

The effect of Fe concentration on $\mathrm{Si} V_{\max }$ in waters within the Polar Frontal Zone $\left(\sim 62^{\circ} \mathrm{S}\right)$ was measured both in austral spring (Expt 1) and summer (Expt 4). Higher dissolved Fe concentrations resulted in higher Si $V_{\max }$ values in both experiments, although not on all days. In the spring (Expt 1), Fe addition did not have an apparent effect on $V_{\max }$ until Day 12 (Fig. 2). A similarly long lag time occurred before increases were detected in $\mathrm{Si}(\mathrm{OH})_{4}$ and $\mathrm{NO}_{3}{ }^{-}$uptake rates and biogenic $\mathrm{SiO}_{2}$ concentrations in this enrichment as well (Franck et al. 2000). $V_{\max }$ values in the spring Fe additions were anywhere from 0.7 to 1.9 times those in the controls depending on date and Fe addition, and were greatest at Fe concentrations of $\sim 1 \mathrm{nM}$. In the summer (Expt 4), Si $V_{\max }$ values in the Fe additions were 1.1 to 2.0 times those in the controls and were greatest in the enrichments with $\sim 0.5 \mathrm{nM}$ total dissolved Fe. $V_{\max }$ values increased with time in this experiment, and were highest on Day 16, the last day sampled (Fig. 2).

Fe availability had the smallest affect on Si $V_{\max }$ in the experiment conducted to the north of the Polar Frontal Zone (Expt 2). On Day 5, the highest $V_{\max }$ values were measured in waters with $\geq 0.1 \mathrm{nM}$ ambient $\mathrm{Fe}$, but $\mathrm{Fe}$ concentration had no effect on $\mathrm{Si} V_{\max }$ on Day 8, the last day sampled (Fig. 2).

\section{DISCUSSION}

\section{Fe-dependent $\mathrm{Si}(\mathrm{OH})_{4}$ uptake kinetics}

Iron addition significantly affected $\mathrm{Si} V_{\max }$ values in experiments conducted in all 3 HNLC areas (Table 3, Figs. 2 \& 3). With few exceptions, Fe addition increased Si $V_{\max }$ by $\sim 2$ to 3 times relative to controls. These experiments, conducted in widely different regions with very different phytoplankton assemblages, suggest that low Fe availability depresses $\mathrm{Si} V_{\max }$ values in HNLC waters. The data agree well with the one previous study investigating the effect of $\mathrm{Fe}$ on $\mathrm{Si}$ $V_{\max }$, which reported 2 to 3 times higher values in Fe-replete versus $\mathrm{Fe}$-stressed laboratory cultures of Thalassiosira weissflogii (De La Rocha et al. 2000).

Results from the Southern Ocean (Expts 1, 3 and 4) suggest that the effect of $\mathrm{Fe}$ addition on $\mathrm{Si} V_{\max }$ can vary with the level of $\mathrm{Fe}$ addition. In these experiments, Si $V_{\max }$ values were greatest in enrichments with final Fe concentrations $>0.5 \mathrm{nM}$, and Si $V_{\max }$ values seemed to peak at Fe concentrations of $\sim 0.8 \mathrm{nM}$ (Fig. 2). Phytoplankton growth rates in HNLC regions also showed a similar response to increasing Fe concentrations, with maximum growth rates observed at $\sim 1 \mathrm{nM} \mathrm{Fe}$ (Coale et al. 1996, Hutchins et al. 2002). In marine diatoms, the energy for Si biomineralization has been linked to aerobic respiration (Sullivan 1986, Martin-Jézéquel et al. 2001). The respiratory chain has a high $\mathrm{Fe}$ requirement, and it may be that reduced 
electron transport efficiency in Fe-limited diatoms, occurring over a relatively wide range of dissolved Fe concentrations, is one cause for the observed decrease in $\mathrm{Si} V_{\max }$ at low Fe availability.

The time-course experiments in the Southern Ocean show that the effect of Fe addition on $\mathrm{Si} V_{\max }$ and $\mathrm{Si}$ $V_{\text {max }}$ values themselves, can vary with time. This could be due to gradual changes in species composition, $\mathrm{Si}$ transporter synthesis and/or cellular metabolism. It is common to see long lag times in Fe enrichments conducted in the Southern Ocean. These enrichments were maintained for longer time periods, however, and changes in Si $V_{\max }$ over time may also be due to bottle effects, such as sudden declines in phytoplankton abundance or activity. In addition, the Southern Ocean enrichments were not screened and changes in cell physiology due to white-light photoinhibition could have been an issue (Franck et al. 2000). Despite such caveats, the response to Fe seems to be the same in all 3 regions: in general, $\mathrm{Fe}$ addition significantly increased the capacity for $\mathrm{Si}(\mathrm{OH})_{4}$ uptake in marine phytoplankton.

Combined Fe and Zn additions, when conducted, resulted in changes in $\mathrm{Si} V_{\max }$ similar to those produced by $\mathrm{Fe}$ addition (Table 3, Fig. 3). In 2 out of 3 experiments with $\mathrm{Fe}+\mathrm{Zn}$ additions, Si $V_{\max }$ was higher in the $\mathrm{Fe}+\mathrm{Zn}$ treatments than in the Fe treatments, suggesting that Fe and $\mathrm{Zn}$ may have had a synergistic effect on $\mathrm{Si}(\mathrm{OH})_{4}$ uptake. Bruland et al. (1991) first discussed the potential for synergistic effects of trace metals on phytoplankton biology. One reason for such an effect may be that Fe-stimulated increases in phytoplankton growth and photosynthetic activity lead to increases in carbonic anhydrase activity and an increased requirement for $\mathrm{Zn}$. It is unlikely that the apparent synergistic effect of $\mathrm{Fe}+$ Zn could be due to changes in microplankton species composition. In all 3 experiments with $\mathrm{Fe}+\mathrm{Zn}$ additions, total cell numbers were greatest in the $\mathrm{Fe}+\mathrm{Zn}$ enrichments but, for the most part, there was little if any difference in the relative proportion of the major phytoplankton groups among the $\mathrm{Zn}, \mathrm{Fe}$ and $\mathrm{Fe}+\mathrm{Zn}$ enrichments (Tables $6 \& 7$ ). These groups included Chaetoceros spp., <20 $\mathrm{mm}$ pennate diatoms, Pseudonitzschia spp., Rhizosolenia spp. and non diatoms. An exception is the higher contribution of small pennate diatoms to total cells in the $\mathrm{Fe}+\mathrm{Zn}$ enrichment in the Costa Rica Upwelling Dome experiment (66 vs 40 to $50 \%)$.

There were 2 experiments in which Fe and combined $\mathrm{Fe}+\mathrm{Zn}$ additions significantly decreased, rather than increased, Si $V_{\max }$ (Table 3). These included the Pt Conception experiment off California and the Peru experiment in the eastern tropical Pacific. It seems unlikely that increased Fe availability would cause a decline in the synthesis of $\mathrm{Si}(\mathrm{OH})_{4}$ transporters in the cell walls of diatoms from these locations. We hypothesize that Fe-induced changes in diatom species composition caused the observed declines in $\mathrm{Si} V_{\text {max }}$. With respect to uptake kinetics, changes in the relative abundance of diatom groups, rather than changes in absolute cell numbers, would have more of an effect. In both experiments, there was a decline in the proportion of larger pennate diatoms in the $\mathrm{Fe}$ and $\mathrm{Fe}+\mathrm{Zn}$ enrichments relative to controls (Tables 6 \& 7). In the Pt Conception experiment, the decline in the proportion of pennate diatoms was due to a 13 to $20 \%$ drop in the relative abundance of Pseudo-nitzschia spp. cells, while in the Peru experiment, the decline in the proportion of pennates was due to a $16 \%$ drop in the relative abundance of Nitzschia and Navicula spp. If certain diatom groups have higher $\mathrm{Si} V_{\max }$ values in general, then the bulk $\mathrm{Si} V_{\max }$ value may decline if species compositional changes outweigh environmental effects, including increases in Fe availability. In these 2 experiments, diatoms of the larger Nitzschioid and Naviculoid types would have had to have $\sim 2$-fold higher Si $V_{\max }$ than the rest of the diatom assemblage in order for the observed declines in the relative abundance of these groups to account for the decline in $\mathrm{Si}$ $V_{\text {max }}$. Such a difference seems reasonable. Pennate diatoms tend to have higher surface area:volume ratios than do centric diatoms and thus may have a higher density of silicon transporters by default. In a review of silicon metabolism in diatoms, published values for $\mathrm{Si}$ $V_{\text {max }}$ were routinely higher in pennate species (MartinJézéquel et al. 2001).

The effect of $\mathrm{Fe}$ addition on the half-saturation constant for $\mathrm{Si}(\mathrm{OH})_{4}$ uptake ( $\mathrm{Si} K_{\mathrm{s}}$ ) in natural phytoplankton assemblages was much harder to elucidate in this study given the mixed results of the 4 experiments in which Si $K_{\mathrm{s}}$ was measured. In 3 experiments, Fe addition had no significant effect on $\mathrm{Si} K_{\mathrm{s}}$ (Table 4). In one experiment in upwelling waters off California, however, $\mathrm{Fe}$ addition alone and in combination with Zn significantly increased $\mathrm{Si} K_{\mathrm{s}}$ more than 3 -fold. The increase in $\mathrm{Si} K_{\mathrm{s}}$ suggests that diatom assemblages would become silicon-limited at higher $\mathrm{Si}(\mathrm{OH})_{4}$ concentrations after Fe addition. Only one published study has investigated the effect of $\mathrm{Fe}$ on $\mathrm{Si}(\mathrm{OH})_{4}$ uptake kinetics to date, and this study did not show a significant difference in $\mathrm{Si} K_{\mathrm{s}}$ between Fe-limited and Fereplete laboratory cultures of Thalassiosira weissflogii (De La Rocha et al. 2000).

Healey (1980) observed that $V_{\max }$ as well as $K_{\mathrm{s}}$ determine nutrient uptake rate rates at low nutrient concentrations, and suggested that $V_{\max }: K_{\mathrm{s}}$ ratios would be a better indicator of the relative competitive advantage of a phytoplankton group for nutrient acquisition than $K_{\mathrm{s}}$ estimates alone. An increase in the $V_{\text {max }}: K_{\mathrm{s}}$ ratio 
would indicate an increased ability to utilize nutrients at low concentrations. Based on changes in this ratio, $\mathrm{Fe}$ addition to $\mathrm{Fe}$-stressed waters can substantially increase the competitive advantage of diatom assemblages with respect to $\mathrm{Si}(\mathrm{OH})_{4}$ acquisition, although not consistently. In the Big Sur and Costa Rica experiments, Fe addition increased the $V_{\max }: K_{\mathrm{s}}$ ratio about 3 -fold relative to the controls. In the Pt Arena experiment, $V_{\text {max }}: K_{\mathrm{s}}$ ratios remained relatively constant after Fe addition, despite the fact that Fe addition altered both $\mathrm{Si} V_{\max }$ and $\mathrm{Si} K_{\mathrm{s}}$. Lastly, in the Pt Conception experiment, $\mathrm{Fe}$ addition led to a decrease in the $V_{\max }: K_{\mathrm{s}}$ ratio, to $37 \%$ of the control value.

\section{Fe-dependent $\mathrm{NO}_{3}{ }^{-}$uptake kinetics}

Fe addition significantly increased $\mathrm{NO}_{3}{ }^{-} V_{\max }$ values in enrichment studies conducted at all sites where $\mathrm{NO}_{3}{ }^{-} V_{\text {max }}$ values were measured (Fig. 4, Table 3). For the most part, $\mathrm{NO}_{3}{ }^{-} V_{\max }$ values after Fe addition were more than twice those in the controls. The one experiment in which $\mathrm{Fe}$ addition resulted in only a small $(1.2 \times)$ increase in $\mathrm{NO}_{3}{ }^{-} V_{\max }$ had the highest initial dissolved Fe concentration in this study (Peru, $0.3 \mathrm{nM}$, Table 1), suggesting the phytoplankton assemblage at this site may not have been severely Fe-stressed. Combined $\mathrm{Fe}$ and $\mathrm{Zn}$ additions also significantly increased $\mathrm{NO}_{3}{ }^{-} V_{\text {max }}$ values in all 3 experiments in which $\mathrm{Fe}+\mathrm{Zn}$ enrichments were done. In 2 cases, $\mathrm{NO}_{3}{ }^{-} V_{\max }$ values in the $\mathrm{Fe}+\mathrm{Zn}$ treatments were significantly higher than those in the Fe treatments. As stated previously, this provides evidence for an apparent synergistic effect of combined $\mathrm{Fe}$ and $\mathrm{Zn}$ additions on marine phytoplankton.

To our knowledge, no other experiment has investigated the effect of Fe on nitrate uptake kinetics, either in the laboratory or in the field. Fe is a co-factor in the enzymes nitrate and nitrite reductase (Raven 1976, Timmermans et al. 1994, Milligan \& Harrison 2000), which are essential for $\mathrm{NO}_{3}{ }^{-}$uptake in phytoplankton. Studies have shown that both nitrate and nitrite reductase activities are reduced in Fe-limited phytoplankton in culture (Timmermans et al. 1994, Milligan \& Harrison 2000), and that Fe addition stimulates instantaneous $\mathrm{NO}_{3}{ }^{-}$uptake rates in bottle enrichment experiments in HNLC regions (Price et al. 1991, Timmermans et al. 1998, Franck et al. 2000). This is the first study to look at the effect of Fe availability on $\mathrm{NO}_{3}{ }^{-} V_{\text {max }}$ a key indicator of the maximum rate of new production and, by inference, the maximum rate of $\mathrm{C}$ export from marine ecosystems. Our results suggest that $\mathrm{Fe}$ availability directly regulates $\mathrm{NO}_{3}{ }^{-} V_{\max }$ in HNLC regions.

Whatever the causes for the apparent decline in $\mathrm{Si}$ $V_{\max }$ after Fe addition in 2 of the enrichment experi- ments (see above section), $\mathrm{NO}_{3}^{-} V_{\max }$ values significantly increased in all experiments (Table 3). Thus, it appears that $\mathrm{NO}_{3}{ }^{-}$uptake kinetics are more likely to show Fe stress than are $\mathrm{Si}(\mathrm{OH})_{4}$ uptake kinetics. This observation supports results from a recent study showing that particulate organic nitrogen production was more sensitive to Fe availability than biogenic silica production in HNLC waters off California (Firme et al. 2003). This is not surprising given that the enzymes required for $\mathrm{NO}_{3}{ }^{-}$assimilation are $\mathrm{Fe}$-dependent, and the link between $\mathrm{Fe}$ availability and $\mathrm{Si}(\mathrm{OH})_{4}$ assimilation is probably less direct, as mentioned earlier.

Initial $\mathrm{NO}_{3}{ }^{-}$concentrations were high in these experiments (Table 1). Due to low $\mathrm{NO}_{3}{ }^{-}$drawdown, $\mathrm{NO}_{3}{ }^{-}$ concentrations remained too high in control and $\mathrm{Zn}$ enrichments to measure half-saturation constants for $\mathrm{NO}_{3}{ }^{-}$uptake $\left(\mathrm{NO}_{3}{ }^{-} K_{\mathrm{S}}\right)$ in 3 of the experiments in which measurements of $\mathrm{NO}_{3}{ }^{-} K_{\mathrm{s}}$ were attempted (Table 4). It was possible to measure $\mathrm{NO}_{3}{ }^{-} K_{\mathrm{s}}$ in all 4 enrichments in the Costa Rica Upwelling Dome experiment. In this experiment, Fe did not have a significant effect on $\mathrm{NO}_{3}{ }^{-} K_{\mathrm{s}}$. Fe addition did increase the $V_{\text {max }}: K_{\mathrm{s}}$ ratio more than 4 -fold, suggesting that Fe addition greatly improved the ability of the phytoplankton in these waters to acquire $\mathrm{NO}_{3}{ }^{-}$at low concentrations (Healy 1980).

It should be noted that high $\mathrm{NH}_{4}{ }^{+}$concentrations can inhibit $\mathrm{NO}_{3}{ }^{-}$uptake in phytoplankton (Dortch 1990, Harrison et al. 1996). Ammonium concentrations were not monitored in the individual enrichments, and it is possible that differences in $\mathrm{NH}_{4}{ }^{+}$accumulation during the course of the experiments could have contributed to some of the variation observed in $\mathrm{NO}_{3}{ }^{-} V_{\max }$ values. Published values of $K_{\mathrm{i}}$, the half-saturation constant for $\mathrm{NH}_{4}{ }^{+}$inhibition of $\mathrm{NO}_{3}{ }^{-}$uptake, range from 0.40 to $0.6 \mu \mathrm{M} \mathrm{NH}_{4}{ }^{+}$for high-nitrate environments (Price et al. 1994, Harrison et al. 1996, Elskens et al. 1999). Initial $\mathrm{NH}_{4}{ }^{+}$concentrations in our experiments ranged from 0.1 to $0.7 \mu \mathrm{M}$, and so a moderate amount of $\mathrm{NH}_{4}{ }^{+}$inhibition may have occurred in the enrichments. The fact that $\mathrm{Fe}$ addition increased $\mathrm{NO}_{3}^{-} V_{\max }$ in all 6 experiments listed in Table 3, however, suggests that $\mathrm{Fe}$ is regulating $\mathrm{NO}_{3}{ }^{-}$kinetics in low-Fe waters irrespective of potential $\mathrm{NH}_{4}{ }^{+}$inhibition.

Despite the wide variation in initial dissolved Fe concentrations observed among our study sites, it does not appear that initial Fe concentrations are a good predictor of the effect of Fe addition on kinetics parameters. For example, when increases in $\mathrm{Si} V_{\max }$ and $\mathrm{NO}_{3}{ }^{-} V_{\max }$ observed after $\mathrm{Fe}$ addition were plotted as a function of initial Fe concentration, no clear trend emerged. It may be that total dissolved Fe and $\mathrm{Zn}$ measurements, while good indicators of the potential for Fe and $\mathrm{Zn}$ stress, are not good indicators of subtle differences in $\mathrm{Fe}$ and Zn bioavailability. 


\section{Zn-dependent $\mathrm{Si}(\mathrm{OH})_{4}$ uptake kinetics}

The effects of $\mathrm{Zn}$ enrichment on $\mathrm{Si}(\mathrm{OH})_{4}$ uptake kinetics varied widely among experiments. Zn limitation was apparent only in the Big Sur experiment off California, where $\mathrm{Zn}$ addition by itself significantly increased Si $V_{\max }$ (Table 3, Fig. 3). In addition to a lower Si $V_{\max }$ value, the control treatment also had a significantly higher $\mathrm{Si} K_{\mathrm{s}}$ value relative to the $\mathrm{Zn}$ treatment in this experiment (Table 4, Fig. 3). De La Rocha et al. (2000) reported similar differences in $\mathrm{Si} V_{\max }$ and Si $K_{\mathrm{s}}$ between $\mathrm{Zn}$-limited and $\mathrm{Zn}$-replete cultures of the diatom Thalassiosira weissflogii, with $\mathrm{Si} V_{\max }$ values 2.5 times lower in the Zn-limited cultures, and Si $K_{\mathrm{s}}$ values 1.7 times higher $(4.0$ vs $2.4 \mu \mathrm{M})$. The results from the Big Sur region, together with the laboratory data from De La Rocha et al. (2000), support the hypothesis of a zinc-dependent active site for silicon uptake in diatoms, proposed by Rueter \& Morel (1981). A Zn-dependent $\mathrm{Si}$ transporter may explain why oceanic profiles of dissolved Zn co-vary with those of $\mathrm{Si}(\mathrm{OH})_{4}$ (Bruland 1980, Bruland et al. 1994).

$\mathrm{Zn}$ addition alone had no significant effect on Si $V_{\max }$ or Si $K_{\mathrm{s}}$ in any of the other enrichment experiments with $\mathrm{Zn}$, implying that $\mathrm{Zn}$ was limiting only at the Big Sur site. Neither the initial Zn concentration nor the amount of Zn added seemed to have any bearing on the response to $\mathrm{Zn}$ enrichment in these experiments, although the Big Sur experiment had some of the lowest dissolved Zn concentrations in this study. The Big Sur experiment was conducted in coastal waters, and previous studies have shown that coastal phytoplankton have higher requirements for $\mathrm{Zn}$ than in openocean regions (Brand et al. 1983, Sunda \& Huntsman 1992, Tortell \& Price 1996).

\section{Zn-dependent $\mathrm{NO}_{3}{ }^{-}$uptake kinetics}

In addition to increasing $\mathrm{Si} V_{\max }$ Zn addition also significantly increased $\mathrm{NO}_{3}{ }^{-} V_{\max }$ in the Big Sur experiment, further supporting the idea that this site was Znlimited (Table 3, Fig. 4). No previous studies on the effect of dissolved $\mathrm{Zn}$ concentrations on $\mathrm{NO}_{3}{ }^{-}$uptake kinetics, either in the laboratory or in the field, have been reported. Early work by Wacker (1962) linked Zn deficiency with decreased protein synthesis and nitrogen content in the autotrophic flagellate Euglena gracilis, and suggested that $\mathrm{Zn}$ was important for protein synthesis. This could explain the enhancement of $\mathrm{NO}_{3}{ }^{-}$ $V_{\max }$ values after $\mathrm{Zn}$ addition in the Big Sur experiment.

In the remaining 3 experiments in which $\mathrm{Zn}$ enrichments were conducted, $\mathrm{Zn}$ either had no significant effect on $\mathrm{NO}_{3}^{-} V_{\max }$ (Pt Arena), or significantly decreased $\mathrm{NO}_{3}{ }^{-} V_{\max }$ values relative to controls (Pt Con- ception, Costa Rica) (Table 3, Fig. 4). This response to $\mathrm{Zn}$ - either no effect or an actual decline-is similar to previous experiments investigating the effect of $\mathrm{Zn}$ on $\mathrm{NO}_{3}{ }^{-}$assimilation. These experiments either show no change in $\mathrm{NO}_{3}{ }^{-}$drawdown after $\mathrm{Zn}$ addition (Buma et al. 1991, Coale 1991) or show a decrease in $\mathrm{NO}_{3}{ }^{-}$ uptake rates (Franck et al. 2000).

It is possible that $\mathrm{Zn}$ toxicity may have caused the depressed $\mathrm{NO}_{3}{ }^{-} V_{\max }$ values observed in some of our experiments, although studies show that $\mathrm{Zn}$ toxicity is unlikely in marine phytoplankton at concentrations $<1 \mu \mathrm{M}$ (Fisher \& Frood 1980, Stauber \& Florence 1990, Tadros et al. 1990). Decreases in $\mathrm{NO}_{3}{ }^{-} V_{\max }$ in these experiments are not likely to be a result of shifts in species composition, as the proportions of the dominant phytoplankton groups in the $\mathrm{Zn}$ enrichments were somewhere in between the controls and Fe enrichments (Tables 5 \& 6). When $\mathrm{Zn}$ was added at the same concentration in combination with $\mathrm{Fe}$ at the Pt Conception and Costa Rica locations, $\mathrm{NO}_{3}{ }^{-} V_{\max }$ increased relative to the $\mathrm{Fe}$ additions. If lower $\mathrm{NO}_{3}{ }^{-} V_{\max }$ values in the $\mathrm{Zn}$ additions were due to $\mathrm{Zn}$ toxicity, the lack of $\mathrm{Zn}$ toxicity in the combined $\mathrm{Fe}+\mathrm{Zn}$ additions may be because $\mathrm{Fe}$ increases the cellular demand for $\mathrm{Zn}$, as hypothesized previously. Alternately, Zn may competitively inhibit $\mathrm{Fe}$ uptake, resulting in a higher likelihood for Zn toxicity at low Fe concentrations. It has been shown that $\mathrm{Zn}$ can be toxic for this reason at low Mn concentrations (Sunda 1991), although no work has demonstrated a competitive effect at low Fe concentrations.

The conflicting effects of $\mathrm{Zn}$ addition on $\mathrm{NO}_{3}{ }^{-}$kinetics in the Costa Rica Upwelling Dome enrichment (lower $V_{\max }$ but higher substrate affinity) and the lack of a clear trend among the other 3 experiments suggest that the effects of Zn addition may be mediated by complicating factors such as phytoplankton species composition, organic complexation, intracellular Zn reserves or the availability of other trace metals such as Fe.

\section{Fe- and $\mathrm{Zn}$-dependent $\mathrm{Si}(\mathrm{OH})_{4}: \mathrm{NO}_{3}{ }^{-}$drawdown ratios and $\mathrm{Si}(\mathrm{OH})_{4}: \mathrm{NO}_{3}{ }^{-} V_{\max }$ ratios}

In general, $\mathrm{Fe}$ and $\mathrm{Fe}+\mathrm{Zn}$ additions significantly decreased $\mathrm{Si}(\mathrm{OH})_{4}: \mathrm{NO}_{3}{ }^{-}$drawdown ratios. Similar changes were seen in $\mathrm{Si}(\mathrm{OH})_{4}: \mathrm{NO}_{3}{ }^{-} V_{\max }$ ratios. The decline in drawdown and $V_{\max }$ ratios after Fe addition was due mainly to the fact that $\mathrm{Fe}$ stimulated $\mathrm{NO}_{3}{ }^{-}$ drawdown and $\mathrm{NO}_{3}{ }^{-} V_{\max }$ more so than $\mathrm{Si}(\mathrm{OH})_{4}$ drawdown and $\mathrm{Si} V_{\max }$. A similar cause has been postulated for decreases in $\mathrm{Si}(\mathrm{OH})_{4}: \mathrm{NO}_{3}{ }^{-}$uptake ratios after $\mathrm{Fe}$ addition in experiments conducted in the Southern Ocean (Franck et al. 2000) and in waters off California (Firme et al. 2003). 
$\mathrm{Zn}$ addition increased rather than decreased $\mathrm{Si}(\mathrm{OH})_{4}$ : $\mathrm{NO}_{3}{ }^{-}$drawdown and $V_{\text {max }}$ ratios. In 2 experiments, at the Pt Conception and Costa Rica Upwelling Dome locations, the increase in $\mathrm{Si}(\mathrm{OH})_{4}: \mathrm{NO}_{3}{ }^{-}$drawdown and $V_{\text {max }}$ ratios was due to a decline in $\mathrm{NO}_{3}{ }^{-}$drawdown and $\mathrm{NO}_{3}{ }^{-} V_{\text {max }}$ following $\mathrm{Zn}$ addition, perhaps due to $\mathrm{Zn}$ toxicity (see 'Zn-dependent $\mathrm{NO}_{3}{ }^{-}$uptake kinetics' above). At the Big Sur location in waters off California, the increase in $\mathrm{Si}(\mathrm{OH})_{4}: \mathrm{NO}_{3}{ }^{-}$drawdown and $V_{\max }$ ratios was due instead to a $\mathrm{Zn}$-stimulated increase in $\mathrm{Si}(\mathrm{OH})_{4}$ drawdown and Si $V_{\max }$ (Table 3).

Previous $\mathrm{Fe}$ enrichment experiments have also reported higher $\mathrm{Si}(\mathrm{OH})_{4}: \mathrm{NO}_{3}{ }^{-}$uptake and drawdown ratios in Fe-stressed versus Fe-replete waters, and shown declines in these ratios after Fe addition. To date, higher $\mathrm{Si}(\mathrm{OH})_{4}: \mathrm{NO}_{3}{ }^{-}$drawdown and uptake ratios have been reported in upwelling waters off California near Big Sur (Hutchins \& Bruland 1998, Hutchins et al. 1998), in the Southern Ocean (Takeda 1998, Franck et al. 2000), in the subarctic North Pacific (Takeda 1998) and in the eastern tropical Pacific (Takeda 1998, Hutchins et al. 2002). Higher $\mathrm{Si}(\mathrm{OH})_{4}: \mathrm{NO}_{3}{ }^{-}$drawdown ratios and higher cellular Si:N biomass ratios have also been demonstrated in Fe-limited versus Fe-replete diatom cultures (Takeda 1998, De La Rocha et al. 2000).

This study is the first to look at the effect of $\mathrm{Zn}$ on $\mathrm{Si}(\mathrm{OH})_{4}: \mathrm{NO}_{3}{ }^{-}$drawdown ratios, and the effect of Fe and $\mathrm{Zn}$ on $\mathrm{Si} V_{\max }: \mathrm{NO}_{3}{ }^{-} V_{\max }$ ratios. Based on our results, higher $\mathrm{Si}(\mathrm{OH})_{4}: \mathrm{NO}_{3}{ }^{-}$drawdown ratios in low$\mathrm{Fe}$ and/or high-Zn waters may be due to the effects of Fe and $\mathrm{Zn}$ on $\mathrm{Si}(\mathrm{OH})_{4}$ and $\mathrm{NO}_{3}{ }^{-}$uptake kinetics, specifically to $\mathrm{NO}_{3}{ }^{-} V_{\text {max }}$. It appears that lower $\mathrm{Si}(\mathrm{OH})_{4}: \mathrm{NO}_{3}{ }^{-}$ drawdown ratios in HNLC regions are, at least in part, a result of the preferential depression of $\mathrm{NO}_{3}{ }^{-} V_{\text {max }}$ relative to $\mathrm{Si} V_{\max }$ at low $\mathrm{Fe}$ or high $\mathrm{Zn}$ concentrations.

The question remains whether higher $\mathrm{Si}(\mathrm{OH})_{4}: \mathrm{NO}_{3}{ }^{-}$ drawdown ratios observed in HNLC regions result in more heavily silicified diatoms. To date, 2 studies report that Fe-limited diatoms grown in culture can have 1- to 2-times higher Si per cell (Takeda 1998, De La Rocha et al. 2000). Higher Si per cell would suggest that Fe-limited diatoms either have higher biomassspecific $\mathrm{Si}(\mathrm{OH})_{4}$ uptake rates, or spend more time in cell cycle stages where $\mathrm{Si}(\mathrm{OH})_{4}$ uptake occurs (e.g. G1, G2 and M, Brzezinski et al. 1990, Martin-Jézéquel et al. 2001). Franck et al. (2000) reported lower biomassspecific $\mathrm{Si}(\mathrm{OH})_{4}$ uptake rates in Fe-limited waters in the Southern Ocean, which are in agreement with the reduced $\mathrm{Si}(\mathrm{OH})_{4}$ uptake capacity of Fe-limited versus Fe-replete phytoplankton assemblages reported in this study. Given lower biomass-specific $\mathrm{Si}(\mathrm{OH})_{4}$ uptake rates and reduced $\mathrm{Si}(\mathrm{OH})_{4}$ uptake capacities, Festressed diatom cells would have to spend significantly more time in cell-cycle stages where Si deposition occurs in order to become more silicified.
It should be noted that higher $\mathrm{Si}(\mathrm{OH})_{4}: \mathrm{NO}_{3}{ }^{-}$drawdown ratios and higher $\mathrm{Si}: \mathrm{N}$ and $\mathrm{Si}: \mathrm{C}$ biomass ratios do not necessarily suggest more Si per cell. Fe limitation can reduce the biovolume (Takeda 1998) as well as the photosynthetic capacity (Milligan \& Harrison 2000) of marine phytoplankton cells. Even if the amount of $\mathrm{Si}$ per cell remained constant, phytoplankton cells with less biovolume and thus less organic matter would exhibit higher $\mathrm{Si}(\mathrm{OH})_{4}: \mathrm{NO}_{3}{ }^{-}$drawdown ratios and higher Si:N and Si:C biomass ratios. Similarly, if a reduction in nitrate and/or nitrite reductase activity forced Fe-limited cells to switch from $\mathrm{NO}_{3}{ }^{-}$as their primary nitrogen source to $\mathrm{NH}_{4}{ }^{+}$, urea or DON, $\mathrm{Si}(\mathrm{OH})_{4}: \mathrm{NO}_{3}{ }^{-}$drawdown ratios would increase without a corresponding increase in Si per cell.

\section{CONCLUSION}

The few laboratory and field studies that have investigated the effects of $\mathrm{Fe}$ on $\mathrm{Si}(\mathrm{OH})_{4}$ uptake kinetics to date suggest that $\mathrm{Fe}$ availability can directly control the density of $\mathrm{Si}(\mathrm{OH})_{4}$ transporters in diatom cell walls. Based on this study, we suggest that Fe availability can also directly control the density of active $\mathrm{NO}_{3}^{-}$transporters in marine phytoplankton. Phytoplankton communities in HNLC regions are probably operating at near-maximum uptake capacities, due to high nutrient concentrations. Our study shows that Fe availability can directly regulate nutrient uptake capacity in low-Fe waters, which may explain why nutrient drawdown is minimal in HNLC regions. By regulating maximum potential $\mathrm{NO}_{3}^{-}$ uptake rates, Fe availability is also regulating new production and the upper level of export flux from HNLC regions as well. The preferential depression of $\mathrm{NO}_{3}{ }^{-} V_{\text {max }}$ relative to $\mathrm{Si} V_{\max }$ observed in this study may help explain why $\mathrm{Si}(\mathrm{OH})_{4}: \mathrm{NO}_{3}{ }^{-}$uptake ratios are higher in low-Fe waters, and why seasonal $\mathrm{Si}(\mathrm{OH})_{4}$ limitation can occur while ambient $\mathrm{NO}_{3}{ }^{-}$concentrations remain saturating. Further work is needed to address whether Fe plays a physiological role in transporter synthesis and function, or whether altered $\mathrm{Si}(\mathrm{OH})_{4}$ and $\mathrm{NO}_{3}{ }^{-}$uptake kinetics are mostly a result of Fe effects on cell metabolism and protein synthesis. Based on results from this study, it is uncertain whether Fe availability affects the affinity of $\mathrm{Si}(\mathrm{OH})_{4}$ and $\mathrm{NO}_{3}{ }^{-}$transporters. Nutrient uptake affinity can control the concentrations at which field populations become nutrient-limited, thereby influencing phytoplankton species composition and plankton succession during seasonal or bloom-induced changes in nutrient concentration. It is important that future studies identify whether Fe availability can alter $K_{\mathrm{s}}$ in individual species and in mixed phytoplankton assemblages. 
Acknowledgements. The authors are indebted to G. Smith at University of California Santa Cruz (UCSC), in particular, as well as the Trace Metals Group at Moss Landing Marine Laboratories (MLML), for engineering and operating the trace-metal clean seawater collection systems at sea and for providing measurements of dissolved $\mathrm{Fe}$ and $\mathrm{Zn}$. We also thank E. Rue, J. Conn, G. Firme, M. Finklestein, D. Weeks, R. Petty, J. Jones and the captains and crews of the RV 'Point Sur', the RV 'Melville' and the RV 'Roger Revelle' for providing measurements and/or help at sea, and R. Sambrotto and S. Green for help with mass spectrometry analysis. We gratefully acknowledge the scientific and editorial input provided by A. Stuart-Oaten, A. Alldredge, B. Prezelin and multiple anonymous reviewers. This research was funded by a NSF Graduate Research Fellowship and Doctoral Dissertation Improvement Grant, and by NSF Grants GER 9453991 (A. Alldredge), OPP 9530762 (K. Coale), OCE 9811114 (K.W.B.), OCE 9811062 (D.A.H.) and OPP 9531982 (M.A.B).

\section{LITERATURE CITED}

Anderson MA, Morel FMM, Guillard RRL (1978) Growth limitation of a coastal diatom by low zinc ion activity. Nature 276:70-71

Boyd P, LaRoche J, Gall M, Frew R, McKay RML (1999) Role of iron, light and silicate in controlling algal biomass in subantarctic waters SE of New Zealand. J Geophys Res 104:13395-13408

Brand LE, Sunda WG, Guillard RRL (1983) Limitation of marine phytoplankton reproductive rates by zinc, manganese, and iron. Limnol Oceanogr 28:1182-1198

Bruland KW (1980) Oceanographic distributions of cadmium, zinc, nickel, and copper in the North Pacific. Earth Planet Sci Lett 47:176-198

Bruland KW, Franks RP, Knauer GA, Martin JH (1979) Sampling and analytical methods for the determination of copper, cadmium, zinc and nickel at the nanogram per liter level in sea water. Anal Chim Acta 105:233-245

Bruland KW, Donat JR, Hutchins DA (1991) Interactive influences of bioactive trace metals on biological production in oceanic waters. Limnol Oceanogr 36:1555-1577

Bruland KW, Orians KJ, Cowen JP (1994) Reactive metals in the stratified central North Pacific. Geochim Cosmochim Acta 58:3171-3182

Bruland KW, Rue EL, Smith G (2001) Iron and macronutrients in coastal upwelling regimes: implications for diatom blooms. Limnol Oceanogr 46:1661-1674

Brzezinski MA (1985) The Si:C:N ratio of marine diatoms: interspecific variability and the effect of some environmental variables. J Phycol 21:347-357

Brzezinski MA, Phillips DR (1997) Evaluation of ${ }^{32} \mathrm{Si}$ as a tracer for measuring silica production rates in marine waters. Limnol Oceanogr 42:856-865

Brzezinski MA, Olson RJ, Chisholm SW (1990) Silicon availability and cell-cycle progression in marine diatoms. Mar Ecol Prog Ser 67:83-96

Buma AGJ, de Baar HJW, Nolting RF, van Bennekom AJ (1991) Metal enrichment experiments in the WeddellScotia Seas: effects of iron and manganese on various plankton communities. Limnol Oceanogr 36:1865-1878

Coale KH (1991) Effects of iron, manganese, copper, and zinc enrichments on productivity and biomass in the subarctic Pacific. Limnol Oceanogr 36:1851-1864

Coale KH, Johnson KS, Fitzwater SE, Gordon RM and 15 others (1996) A massive phytoplankton bloom induced by an ecosystem-scale iron fertilization experiment in the equatorial Pacific Ocean. Nature 383:495-501

Coale KH, Wang X, Tanner SJ, Johnson KS (2003) Phytoplankton growth and biological response to iron and zinc addition in the Ross Sea and Antarctic Circumpolar Current along $170^{\circ} \mathrm{W}$. Deep-Sea Res II 50:635-653

Cupp EE (1943) Marine plankton diatoms of the West Coast of North America. Bulletin of the Scripps Institution of Oceanography of the University of California, 5. University of California Press, Berkeley

De La Rocha CL, Hutchins DA, Brzezinski MA, Zhang Y (2000) Effects of iron and zinc deficiency on elemental composition and silica production by diatoms. Mar Ecol Prog Ser 195:71-79

Dortch Q (1990) The interaction between $\mathrm{NH}_{4}$ and $\mathrm{NO}_{3}$ uptake in phytoplankton. Mar Ecol Prog Ser 61:183-201

Dugdale RC, Goering JJ (1967) Uptake of new and regenerated forms of nitrogen in primary productivity. Limnol Oceanogr 12:196-206

Dugdale RC, Wilkerson FP (1998) Silicate regulation of new production in the equatorial Pacific upwelling. Nature 391:270-273

Dugdale RC, Wilkerson FP, Minas HJ (1995) The role of a silicate pump in driving new production. Deep-Sea Res I 42: $697-719$

Elskens M, Goeyens L, Dehairs F, Rees A, Joint I, Baeyens W (1999) Improved estimation of f-ratio in natural phytoplankton assemblages. Deep-Sea Res I 46:1793-1808

Eppley RW, Rogers JN, McCarthy JJ (1969) Half-saturation constants for uptake of nitrate and ammonium by marine phytoplankton. Limnol Oceanogr 14:912-920

Firme GF, Rue EL, Weeks DA, Hutchins DA (2003) Spatial and temporal variability in phytoplankton iron limitation along the California coast and consequences for $\mathrm{Si}, \mathrm{N}$ and C biogeochemistry. Global Biogeochem Cycles 17:1016

Fisher NS, Frood D (1980) Heavy metals and marine diatoms: influence of dissolved organic compounds on toxicity and selection for metal tolerance among four species. Mar Biol 59:85-93

Franck VM, Brzezinski MA, Coale KH, Nelson DM (2000) Iron and silicic acid concentrations regulate $\mathrm{Si}$ uptake north and south of the Polar Frontal Zone in the Pacific Sector of the Southern Ocean. Deep-Sea Res 47: 3315-3338

Glover HE, Prezelin BB, Campbell L, Wyman M, Garside C (1988) A nitrate-dependent Synechococcus bloom in surface Sargasso Sea water. Nature 331:161-163

Harrison WG, Harris LR, Irwin BD (1996) The kinetics of nitrogen utilization in the oceanic mixed layer: nitrate and ammonium interactions at nanomolar concentrations. Limnol Oceanogr 41:16-32

Healey FP (1980) Slope of the Monod equation as an indicator of advantage in nutrient competition. Microb Ecol 5: 281-286

Hutchins DA, Bruland KW (1998) Iron-limited diatom growth and Si:N uptake ratios in a coastal upwelling regime. Nature 393:561-564

Hutchins DA, DiTullio GR, Bruland KW (1993) Iron and regenerated production: evidence for biological iron recycling in two marine environments. Limnol Oceanogr 38: 1242-1255

Hutchins DA, DiTullio GR, Zhang Y, Bruland KW (1998) An iron limitation mosaic in the California upwelling regime. Limnol Oceanogr 43:1037-1054

Hutchins DA, Sedwick PN, DiTullio GR, Boyd PW, Queguiner B, Griffiths FB, Crossley C (2001) Control of phytoplankton growth by iron and silicic acid availability in the sub- 
antarctic Southern Ocean: experimental results from the SAZ Project. J Geophys Res 106:31559-31572

Hutchins DA, Hare CE, Weaver RS, Zhang Y and 11 others (2002) Phytoplankton iron limitation in the Humboldt Current and Peru Upwelling. Limnol Oceanogr 47:997-1011

Kanda J, Saino T, Hattori A (1985) Nitrogen uptake by natural populations of phytoplankton and primary production in the Pacific Ocean: regional variability of uptake capacity. Limnol Oceanogr 30:987-999

Kirchman DL, Moss J, Keil RG (1992) Nitrate uptake by heterotrophic bacteria: does it change the f-ratio? Adv Limnol 37: 129-138

Kudo I, Harrison PJ (1997) Effect of iron nutrition on the marine cyanobacterium Synechococcus grown on different N sources and irradiances. J Phycol 33:232-240

Martin JH, Fitzwater SE, Gordon RM (1990) Iron deficiency limits phytoplankton growth in Antarctic waters. Global Biogeochem Cycles 4:5-12

Martin-Jézéquel V, Hildebrand M, Brzezinski MA (2001) Silicon metabolism in diatoms: implications for growth. J Phycol 36:821-840

Milligan AJ, Harrison PJ (2000) Effects of non-steady-state iron limitation on nitrogen assimilatory enzymes in the marine diatom Thalassiosira weissflogii (Bacillariophyceae). J Phycol 36:78-86

Nelson DM, Brzezinski MA, Sigmon DE, Franck VM (2001) A seasonal progression of Si limitation in the Pacific sector of the Southern Ocean. Deep-Sea Res II 48:3973-3995

Price NM, Andersen LF, Morel FMM (1991) Iron and nitrogen nutrition of equatorial Pacific plankton. Deep-Sea Res A 38:1361-1378

Price NM, Ahner BA, Morel FMM (1994) The Equatorial Pacific Ocean: grazer-controlled phytoplankton populations in an iron-limited ecosystem. Limnol Oceanogr 39: 520-534

Raven JA (1976) Division of labor between chloroplasts and cytoplasm. In: Barber J (ed) The intact chloroplast. Elsevier, Amsterdam

Rue EL, Bruland KW (1995) Complexation of iron(III) by natural organic ligands in the Central North Pacific as determined by a new competitive ligand equilibration/ adsorptive cathodic stripping voltammetric method. Mar Chem 50:117-138

Rue EL, Bruland KW (1997) The role of organic complexation on ambient iron chemistry in the equatorial Pacific Ocean and the response of a mesoscale iron addition experiment. Limnol Oceanogr 42:901-910

Rueter JG, Morel FMM (1981) The interaction between zinc

Editorial responsibility: Otto Kinne (Editor),

Oldendorf/Luhe, Germany deficiency and copper toxicity as it affects the silicic acid uptake mechanisms in Thalassiosira pseudonana. Limnol Oceanogr 26:67-73

Smith WO Jr, Anderson RF, Moore JK, Codispoti LA, Morrison JM (2000) The US Southern Ocean Joint Global Ocean Flux Study: an introduction to AESOPS. Deep-Sea Res II 47:3073-3093

Stauber JL, Florence TM (1990) Mechanism of toxicity of zinc to the marine diatom Nitzschia closterium. Mar Biol 105: $519-524$

Sullivan CW (1986) Silicification by diatoms. In: Evered D, O'Connor M (eds) Silicon biochemistry, Ciba Foundation Symposium 121. John Wiley \& Sons, New York, p 59-89

Sunda WG (1991) Trace metal interactions with marine phytoplankton. Biol Oceanogr 6:411-442

Sunda WG, Huntsman SA (1992) Feedback interactions between zinc and phytoplankton in seawater. Limnol Oceanogr 37:25-40

Sunda WG, Swift DG, Huntsman SA (1991) Low iron requirement for growth in oceanic phytoplankton. Nature 351: $55-57$

Tadros MG, Mbuthia P, Smith W (1990) Differential response of marine diatoms to trace metals. Bull Environ Contam Toxicol 44:826-831

Takeda S (1998) Influence of iron availability on nutrient consumption ratio of diatoms in oceanic waters. Nature 393 $774-777$

Throndsen J (1978) Preservation and storage. In: Sournia A (ed) Phytoplankton manual. UNESCO, Paris, p 69-74

Timmermans KR, Stolte W, de Baar HJW (1994) Iron-mediated effects on nitrate reductase in marine phytoplankton. Mar Biol 121:389-396

Timmermans KR, van Leeuwe MA, de Jong JTM, McKay RML and 6 others (1998) Iron stress in the Pacific region of the Southern Ocean: evidence from enrichment assays. Mar Ecol Prog Ser 166:27-41

Tomas CR (1997) Identifying marine phytoplankton. Academic Press, San Diego

Tortell PD, Price NM (1996) Cadmium toxicity and zinc limitation in centric diatoms of the genus Thalassiosira. Mar Ecol Prog Ser 138:245-254

Wacker WEC (1962) Nucleic acids and metals. III. Changes in nucleic acid, protein, and metal content as a consequence of zinc deficiency in Euglena gracilis. Biochemistry 1: 859-865

Wong CS, Matear RJ (1999) Sporadic silicate limitation of phytoplankton productivity in the subarctic NE Pacific. Deep-Sea Res II 46:2539-2555

Submitted: March 21, 2002; Accepted: December 3, 2002

Proofs received from author(s): April 7, 2003 